\title{
Temperate carbonate cycling and water mass properties from intertidal to bathyal depths (Azores)
}

\author{
M. Wisshak ${ }^{1}$, A. Form ${ }^{2}$, J. Jakobsen ${ }^{3}$, and A. Freiwald ${ }^{4}$ \\ ${ }^{1}$ GeoZentrum Nordbayern, Universität Erlangen-Nürnberg, 91054 Erlangen, Germany \\ ${ }^{2}$ IFM-GEOMAR, Marine Biogeochemistry, 24105 Kiel, Germany \\ ${ }^{3}$ Rebikoff-Niggeler Foundation, 9900-451 Horta, Azores, Portugal \\ ${ }^{4}$ Forschungsinstitut Senckenberg, Abteilung für Meeresforschung, 26382 Wilhelmshaven, Germany
}

Received: 31 March 2010 - Published in Biogeosciences Discuss.: 6 May 2010

Revised: 12 July 2010 - Accepted: 22 July 2010 - Published: 13 August 2010

\begin{abstract}
The rugged submarine topography of the Azores supports a diverse heterozoan association resulting in intense biotically-controlled carbonate-production and accumulation. In order to characterise this cold-water (C) factory a 2-year experiment was carried out in the southern Faial Channel to study the biodiversity of hardground communities and for budgeting carbonate production and degradation along a bathymetrical transect from the intertidal to bathyal $500 \mathrm{~m}$ depth.

Seasonal temperatures peak in September (above a thermocline) and bottom in March (stratification diminishes) with a decrease in amplitude and absolute values with depth, and tidal-driven short-term fluctuations. Measured seawater stable isotope ratios and levels of dissolved nutrients decrease with depth, as do the calcium carbonate saturation states. The photosynthetic active radiation shows a base of the euphotic zone in $\sim 70 \mathrm{~m}$ and a dysphotic limit in $\sim 150 \mathrm{~m}$ depth.

Bioerosion, being primarily a function of light availability for phototrophic endoliths and grazers feeding upon them, is $\sim 10$ times stronger on the illuminated upside versus the shaded underside of substrates in the photic zone, with maximum rates in the intertidal $\left(-631 \mathrm{~g} / \mathrm{m}^{2} / \mathrm{yr}\right)$. Rates rapidly decline towards deeper waters where bioerosion and carbonate accretion are slow and epibenthic/endolithic communities take years to mature. Accretion rates are highest in the lower euphotic zone $\left(955 \mathrm{~g} / \mathrm{m}^{2} / \mathrm{yr}\right)$, where the substrate is less prone to hydrodynamic force. Highest rates are found - inversely to bioerosion - on down-facing substrates, suggesting that bioerosion may be a key factor governing the prefer-
\end{abstract}

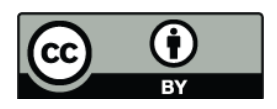

Correspondence to: $\mathrm{M}$. Wisshak (max.wisshak@gzn.uni-erlangen.de) ential settlement and growth of calcareous epilithobionts on down-facing substrates.

In context of a latitudinal gradient, the Azores carbonate cycling rates plot between known values from the coldtemperate Swedish Kosterfjord and the tropical Bahamas, with a total range of two orders in magnitude. Carbonate budget calculations for the bathymetrical transect yield a mean $266.9 \mathrm{~kg}$ of epilithic carbonate production, $-54.6 \mathrm{~kg}$ of bioerosion, and $212.3 \mathrm{~kg}$ of annual net carbonate production per metre of coastline in the Azores $\mathrm{C}$ factory.

\section{Introduction}

The summits and flanks of non-tropical seamounts and volcanic island archipelagos provide a frame for intense biogenic carbonate-production and accumulation, classifying them as important "carbonate factories" of the C factory type (cool water + controlled precipitate; sensu Schlager, 2000). This is because of the availability of hardgrounds in form of the volcanic basement at any depth range, the restricted dilution by volcanoclastics and the hydrodynamically enhanced trophic regime. The result is a pronounced biodiversity including carbonate-secreting benthic organisms (coralline algae, serpulids, molluscs, brachiopods, bryozoans, crinoids, scleractinians, stylasterids, etc.) that have been reported from seamounts and island flanks at any latitudes (see review by Rogers, 1994).

The Azores Archipelago comprises nine volcanic islands and is a prime target for studying a $\mathrm{C}$ factory carbonateproduction centre and its heterozoan association (sensu James, 1997), in the so-called warm-temperate carbonate province (sensu Betzler et al., 1997). The Azores are located

Published by Copernicus Publications on behalf of the European Geosciences Union. 
in a key position in the central North Atlantic in the northeastern segment of the subtropical gyre, framed by the North Atlantic Current in the north and the Azores Current (a recirculating branch of the Gulf Stream) to the south (Santos et al., 1995). The rugged submarine topography of this area is characterised by a high number of seamounts (63 large and 398 small mapped mounts in the Exclusive Economic Zone (EEZ) of the Azores; Morato et al., 2008). Apart from these seamounts, the Faial Channel between the islands Faial and Pico is about to become a research hotspot owing to its remarkable biodiversity (Tempera et al., 2001a, b; Tempera, 2009; see Martins, 1990 for a bibliography on the Azores marine fauna and flora) and has been established as a Marine Protected Area in late 2008. Research in this area is promoted by the proximity to the Department of Oceanography of the Azores University, and the availability of a manned submersible operated by the Rebikoff-Niggeler Foundation, both located in Horta, the capital of Faial.

In 2006 an experimental study was launched with the support of the submersible "Lula" to study the biodiversity of hardground communities and for budgeting carbonate production and degradation along a bathymetric and hydrographic transect covering all photic zones from the shalloweuphotic intertidal to aphotic upper bathyal depths. In the present paper, we characterise this $\mathrm{C}$ factory with respect to (1) general habitat characteristics in the southern Faial Channel, (2) environmental data recorded in situ via highresolution loggers, (3) the photic zonation pattern, (4) water properties such as nutrient and stable isotope signatures, (5) carbonate system parameters, and (6) carbonate accretion and bioerosion rates for different substrate types and orientations. Based on these data we budget the carbonate cycling in this warm-temperate carbonate factory. Detailed assessments of the biodiversity of the calcareous epibenthos, respectively the ichnodiversity of bioeroding biota, will be the subject of consecutive papers.

\section{Material and methods}

\subsection{The experimental design}

The experimental design was modified from the approved setup applied during the Kosterfjord Experiment (Wisshak et al., 2005; Wisshak, 2006). The basic unit were experimental platforms mounted to cliff boulders in the intertidal zone, placed by scuba diving (down to $15 \mathrm{~m}$ water depth), and deployed with the submersible "Lula" (below $15 \mathrm{~m}$ ) along a bathymetric transect in $0,5,15,60,150$ and $500 \mathrm{~m}$ water depth, covering all photic zones from the intertidal to aphotic depths (Fig. 1). At each depth station two panels were deployed, the first of which was recovered after one year and the second subset after 2 years of exposure. Significant damage to the experimental frames, due to hydrodynamic force during heavy winter storms, was limited to the loss of one
$5 \mathrm{~m}$ platform, and recovery of the damaged second one, after only 3 months of exposure.

The design of the experimental platforms is illustrated in Fig. 1 and comprises a PVC frame with four concrete filled tube legs. At 5 to $60 \mathrm{~m}$ water depth the platforms were equipped with further concrete weights and the shallower panels were additionally tied to steel anchors driven into the sea-floor. On the platforms various substrates and data loggers were mounted. Three sets of 5 dried and precision weighed substrate replicas $10 \times 10 \times 1 \mathrm{~cm}$ in size of PVC and limestone (sealed on all sides but the upper side with epoxy resin) were mounted with central nylon bolts and nuts in the orientations (1) up-facing, (2) up-facing but located in a grazer exclusion cage, and (3) down-facing. Embedded mollusc shells and Iceland spar crystals serve for a later identification of bioeroding endoliths and their traces. For ensuring relocation, the platforms beyond $60 \mathrm{~m}$ water depth were equipped with a miniature acoustic transmitter attached to a recovery sling that was held upright in the water column by a floating device and label disc.

\subsection{General habitat characterisation}

The general habitat characterisation is based upon direct seafloor observations and photo + video documentation undertaken during a total of 15 submersible and 8 SCUBA dives in the southern Faial Channel. During these dives, selected calcareous epibenthos was sampled, complementing the wealth of epiliths that were found settling on the experimental frames, allowing for a proper taxonomic identification.

\subsection{Logging environmental data}

Year one platforms were equipped with a temperature logger (STAR-ODDI Starmon Mini; 5 min. measurement interval; accuracy $\pm 0.05^{\circ} \mathrm{C}$ ) and year two platforms carried a temperature/salinity recorder (STAR-ODDI DST CT; $20 \mathrm{~min}$. interval; $T$ accuracy $\pm 0.1^{\circ} \mathrm{C} ; S$ accuracy \pm 0.75 ). Salinity is given on the Practical Salinity Scale 1978 (PSS) as established by the UNESCO (1981). The latter logger type turned out to be unsuitable for such a long-term deployment and they where all leaking, so that only a partial readout was achieved. In the intertidal, two HOBO Water Temp Pro temperature sensors ( $30 \mathrm{~min}$. interval; accuracy $\pm 0.2^{\circ} \mathrm{C}$ ) were mounted on the cliff boulders.

\subsection{Light measurements}

The penetration depth of the photosynthetically active radiation (PAR; 400 to $700 \mathrm{~nm}$ wavelength; unit $=\mu \mathrm{mol}$ photons $\mathrm{m}^{-2} \mathrm{~s}^{-1}$ ) was measured with a LICOR Spherical Quantum Sensor (LI-193SA) and data logger (LI-1400) successively lowered from a small boat to minimise shadowing. The data was then translated to percentages with respect 


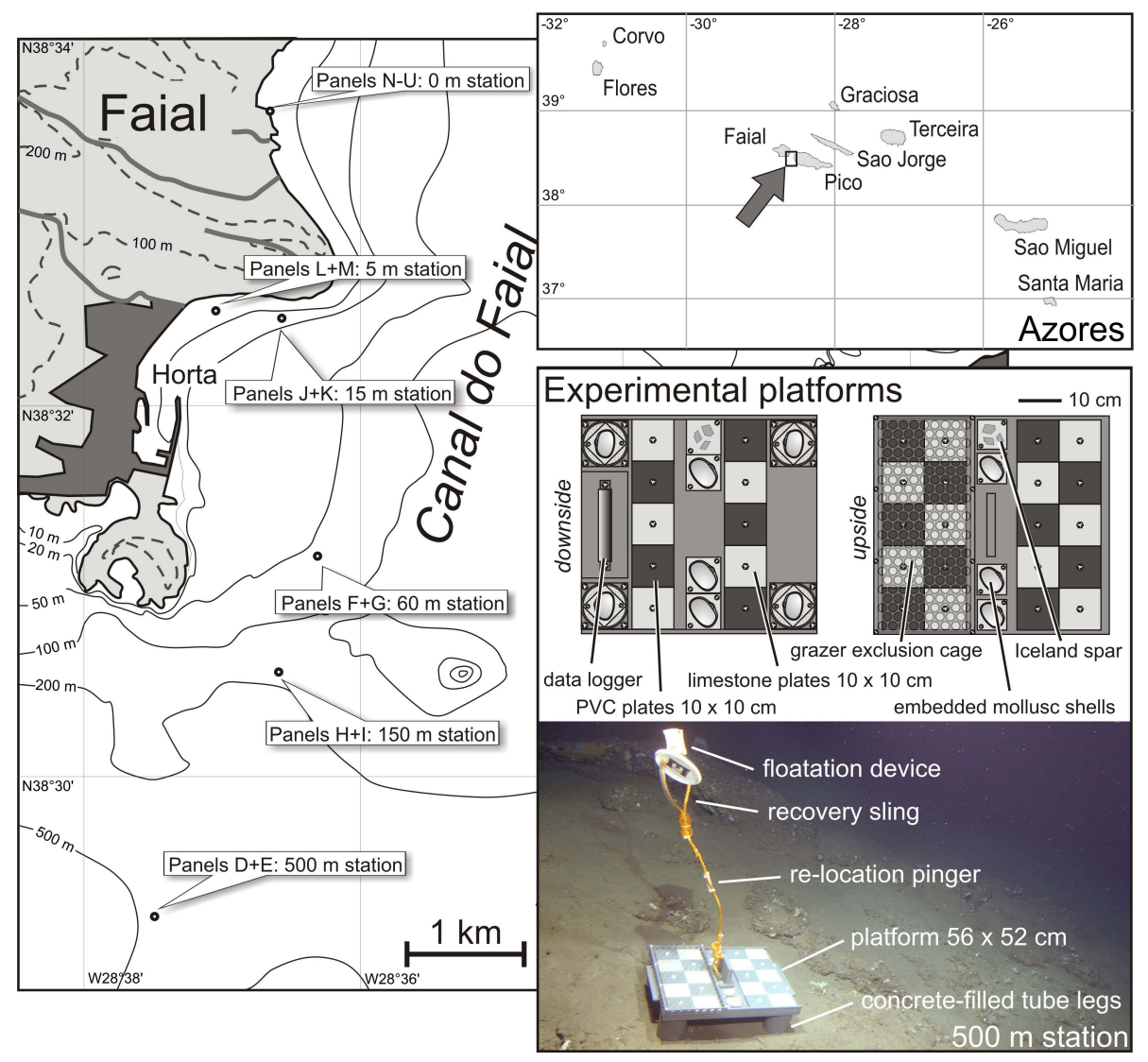

Fig. 1. The bathymetrical transect from the intertidal to $500 \mathrm{~m}$ water depth in the southern Faial Channel (left) located between the islands of Faial and Pico of the central Azores Archipelago (upper right), and the design of the experimental platforms (lower right).

to surface irradiance (measured few centimetres below sealevel). Seven light/depth profiles were logged in late September 2007 and 2008 around midday under a range of weather conditions. At each depth station and in air, 10 measurements were taken and averaged.

\subsection{Analyses of water samples}

During dives in September/October 2007 (Lula dives 123 to 127) and September 2008 (dives 132 to 136), two $100 \mathrm{ml}$ subsamples of ambient sea-water from $60,150,350$ and $500 \mathrm{~m}$ depth were taken via a valve in the submersible, filtered with a $0.2 \mu \mathrm{m}$ PES filter, and immediately treated with $0.1 \mathrm{ml}$ saturated $\mathrm{HgCl}_{2}$ solution before sealing in boron glass bottles.

Oxygen and carbon stable isotope analyses were carried out at the Leibniz-Laboratory in Kiel. Two $0.5 \mathrm{ml}$ sub-samples were analysed on a Finnigan Gas Bench II unit coupled to a Finnigan Delta ${ }^{\text {Plus }}$ XL mass spectrometer. The $\delta^{18} \mathrm{O}_{\mathrm{SW}}$ is given versus V-SMOW with precision of $\pm 0.04 \%$. The $\delta^{13} \mathrm{C}_{\text {DIC }}$ was analysed using a Kiel DICI II device, operated online with a Finnigan Delta E dual-inlet mass spectrometer. The samples were reacted with $2 \mathrm{ml} 30 \%$ phosphoric acid, the $\mathrm{CO}_{2}$ stripped with $\mathrm{N}_{2}$ gas, trapped from carrier gas at liquid nitrogen temperature, distilled from residual water and concentrated in a calibrated volume to measure the $\mathrm{CO}_{2}$ yield. The $\delta^{13} \mathrm{C}_{\text {DIC }}$ is given versus PDB with a standard error of $\pm 0.05 \%$.

Nutrients, total alkalinity (TA), and dissolved inorganic carbon (DIC) were measured at the IFM-GEOMAR in Kiel. Nitrate, nitrite, and phosphate were measured photometrically (Hitachi, U-2000) according to the standard methods by Hansen and Koroleff (1999) with a precision levels of $\pm 0.5, \pm 0.02$, and $\pm 0.05 \mu \mathrm{mol} / \mathrm{l}$. Ammonium was measured fluorometrically (Kontron Instruments, SFM 25) according to Holmes et al. (1999) with a precision of $\pm 0.08 \mu \mathrm{mol} / \mathrm{l}$. TA was measured in duplicate using a potentiometric, opencell titration procedure according to Dickson et al. (2003). $\mathrm{GF} / \mathrm{F}(0.2 \mu \mathrm{m})$ filtered seawater samples of 10 to $15 \mathrm{~g}$ were accurately weighed (Sartorius, 1416B MP8-1) and titrated with $0.005 \mathrm{~N}$ hydrochloric acid $(\mathrm{HCl})$ in an automatic titrator (Metrohm, Titrando 808). The average precision between duplicate measurements was $\leq 4 \mu \mathrm{mol} / \mathrm{kg}$. DIC was measured photochemically according to Stoll et al. (2001) using an automated segmented flow analyzer (Bran+Luebbe, QuAAtro) equipped with an autosampler $( \pm 10 \mu \mathrm{mol} / \mathrm{kg}$ accuracy and $\pm 5 \mu \mathrm{mol} / \mathrm{kg}$ precision). Both, TA and DIC were calibrated with certified seawater reference material (Dickson standard). 


\subsection{Carbonate system calculation}

The carbonate system was computed from the measured temperatures, salinities, phosphates, TA and DIC concentrations using the CO2SYS program (Lewis and Wallace, 1998) with the dissociation constants for carbonic acid of Mehrbach et al. (1973) after the refit of Dickson and Millero (1987). Reported $\mathrm{pH}$-values were given in the total hydrogen scale.

\subsection{Assessment of bioerosion and accretion rates}

After retrieval, the experimental platforms were taken apart and the limestone as well as PVC plates were treated with diluted hydrogen peroxide $\left(\mathrm{H}_{2} \mathrm{O}_{2}\right)$ for up to 5 days in order to remove most of the organic bioaccretion and leave only cemented calcareous skeletons. Any accretion on the lateral faces of the plates was then carefully removed and the plates were dried for several days at $70^{\circ} \mathrm{C}$ before precision scaling (accuracy $\pm 1 \mathrm{mg}$ with a Mettler Toledo AB204-S). The limestone plates were weighed (accuracy $\pm 10 \mathrm{mg}$ with a Mettler Toledo PB3002-S Delta Range) after careful removal of all encrusting calcareous epibionts under the stereo binocular, which were in turn also precision weighed (accuracy $\pm 1 \mathrm{mg}$ with a Mettler Toledo AB204-S). The accretion rates were then calculated by averaging the weight gain of the 5 PVC plates, respectively the weight of the accretion removed from the 5 limestone plates, per orientation divided by the exposure time, and was related to the surface area of the plates of $5 \times 100 \mathrm{~cm}^{2}$ minus $5 \times 2.3 \mathrm{~cm}^{2}$ for the central mounting bolts. These gravimetrically determined carbonate accretion rates are expressed as grams carbonate per square metre and year $\left(\mathrm{g} / \mathrm{m}^{2} / \mathrm{yr}\right)$. The respective bioerosion rates were determined via the weight loss of the limestone plates determined after removal of the carbonate accretion, and are expressed as grams carbonate removed per square metre and year $\left(\mathrm{g} / \mathrm{m}^{2} / \mathrm{yr}\right)$ and thus as negative values.

The experimental substrates within the grazer exclusion cages were omitted from the analysis since considerable sediment trapping within, and epilithic overgrowth on the cages rendered a meaningful interpretation of the results unfeasible.

\section{Results and discussion}

\subsection{The bathymetric transect}

The bathymetrical transect in the southern Faial Channel spans the intertidal shallow euphotic zone down to aphotic $500 \mathrm{~m}$ water depth. The intertidal is characterised by basalt cliffs and wedged boulders (Fig. 2a) encrusted with calcareous rhodo- and chlorophytes as well as the cirripeds Chtalamus stellatus and Megabalanus azoricus. Mobile carbonate producers are the gastropods Littorina striata (Fig. 2b) and Patella candei gomesi alongside the polyplacophoran Lepidochitona simrothi and the echinoid Paracentrotus lividus.
Large boulders also shape the seafloor at the 5 and $15 \mathrm{~m}$ stations with areas of mobile sediment in-between. Calcareous epibenthos is dominated besides calcareous algae by the serpulid Spirobranchus polytrema, the bryozoan genera Aetea, Stephanollona, Escharina, and Scrupocellaria, the cirriped Verruca spengleri, and the vermetid Vermetus rugulosus. The foraminifers Miniacina miniacea and Discoramulina bollii are ubiquitous faunal elements from this depth downward. Among the mobile fauna the pen shell Pinna nobilis is the most conspicuous element (Fig. 2c). Winter storms may cause waves more than $10 \mathrm{~m}$ in height, inducing strong hydrodynamic forces on the seafloor and deployed experimental platforms.

At the $60 \mathrm{~m}$ station, largely below storm wave-base, mixed carbonate-volcanoclastic sand plains show sedimentary structures induced by the tidal currents created in the Faial Channel (Fig. 2c-d). Patches of hardground are occupied or built up by the oyster Neopycnodonte cochlear and the clam Chama circinata (Fig. 2d-e). These benthic islands are colonised by the serpulids Spirobranchus polytrema and Hydroides azoricus, and by a diverse set of the bryozoans Crisia, Omalosecosa, Hippothoa, and Reteporella. Mobile calcifiers are various clams, holothurians and echinoids.

To the south, the seafloor gives way to a well structured slope with many hardground ridges and small mounds that are settled or built up by epibiota such as the Neopycnodonte/Chama bioherms that are dominant at the $150 \mathrm{~m}$ station (Fig. $2 \mathrm{f}-\mathrm{g}$ ). Common serpulids are Spirobranchus polytrema, Filograna gracilis and Hyalopomatus ?marenzelleri, and bryozoans are dominated by Crisia, Hippothoa, Puellina, Celleporina, and Reteporella (Fig. 2h). An increasing number of sponges and hydrozoans are encountered (Fig. 2f). In $\sim 250$ to $400 \mathrm{~m}$ depth, the stylasterid Errina dabneyi and the scleractinians Caryophyllia cyathus and Desmophyllum cristagalli (Fig. 2j), aside large octocoral fans are the most prominent biota. The volcanoclastic fraction of the sediment increases while the grain size decreases towards the deeper slope.

At the $500 \mathrm{~m}$ station, steep fine-grained sediment fans alternate with only partly colonised bedrock outcrops that bear a diverse fauna of sponges, bryozoans (Reteporella and Crisia), serpulids (Hyalopomatus ?marenzelleri and Vitreotubus digeronimoi), cold-water corals (Caryophyllia, Desmophyllum, and Dendrophyllia), the stylasterid Errina dabneyi (Fig. 2i; Wisshak et al., 2009a), the cyrtocrinid Cyathidium foresti (Wisshak et al., 2009b) and the deep-sea oyster Neopycnodonte zibrowii (Fig. 2k; Wisshak et al., 2009c). The latter two primarily thrive protected under hardground overhangs and along steep cliff faces. Mobile calcareous fauna is less abundant apart from the large echinoid Echinus acutus (Fig. 21). 

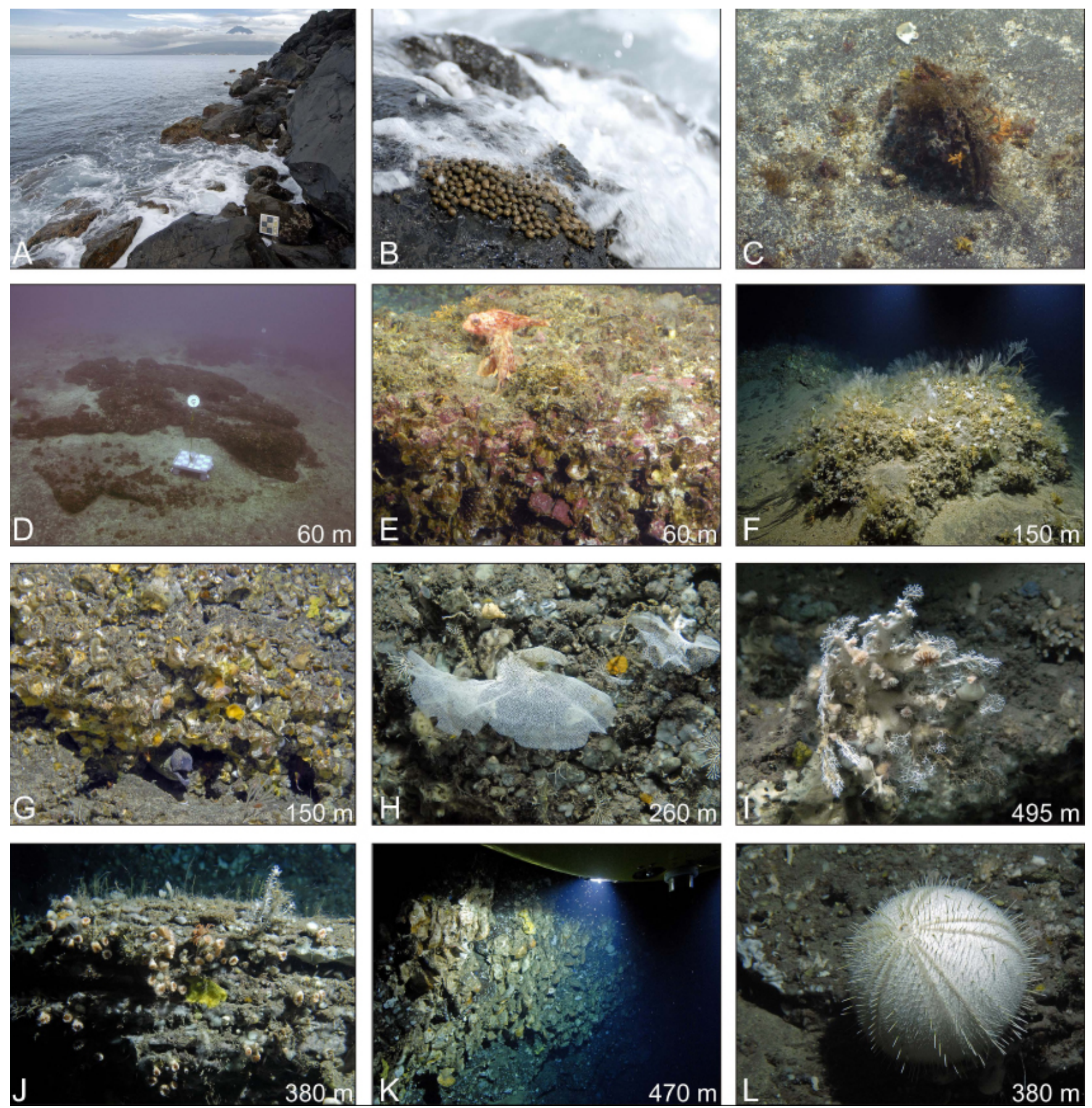

Fig. 2. Typical calcareous faunal elements found along the transect in the southern Faial Channel. (A) Basaltic boulders encrusted by rhodophytes and experimental panels in the upper intertidal. (B) Patches of the gastropod Littorina striata in the intertidal. (C) Sandy mixed calcareous/volcanoclastic sea floor in $60 \mathrm{~m}$ depth with the pen shell Pinna nobilis as benthic island (Lula dive \#118). (D) Sandy plain with patch reefs and experimental platforms at $60 \mathrm{~m}$ depth (dive \#118). (E) The oyster Neopycnodonte cochlear and the clam Chama circinata as main frame builders in $60 \mathrm{~m}$ depth (dive \#122). (F-G) Corresponding reef in $150 \mathrm{~m}$ depth colonised by a diverse set of hydrozoans, sponges, serpulids and bryozoans (dive \#133). (H) Large fan-shaped bryozoan Reteporella in $260 \mathrm{~m}$ depth (dive \#137). (I) The stylasterid Errina dabneyi colonised by Desmophyllum cristagalli in $495 \mathrm{~m}$ depth (dive \#136). (J) Steep canyon walls in $380 \mathrm{~m}$ depth settled by cold-water scleractinians (dive \# 137). (K) Hundreds of deep-sea oysters Neopycnodonte zibrowii thriving at a steep escarpment in $470 \mathrm{~m}$ depth (dive \#134). (L) The large echinoid Echinus acutus in $380 \mathrm{~m}$ depth (dive \#134). 

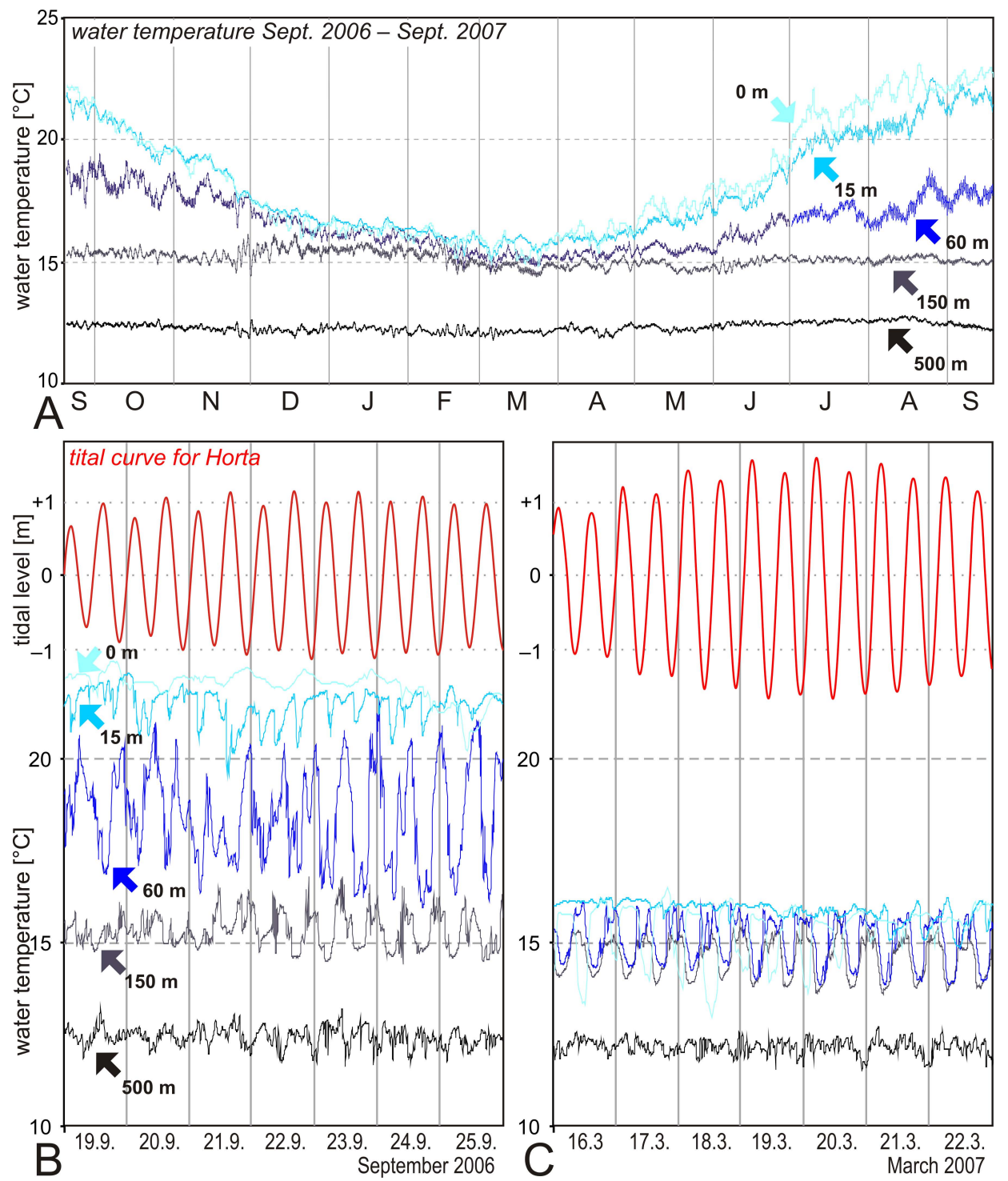

Fig. 3. (A) Temperature logs ( $24 \mathrm{~h}$ running mean) at the various experimental sites showing a sinusoidal seasonality with maximum mean temperatures in September and minimum values in March, decreasing in amplitude and absolute value with depth. (B-C) Hi-res temperature record of one week during spring/neap-tide in September 2006 and March 2007, plotted together with the tidal curve at Horta. Please note that the direct influence of the tidal rhythm upon short-term fluctuations is most pronounced during autumn in $60 \mathrm{~m}$ water depth close to the thermocline that is shifting driven by the tidal currents. During low-temperatures in the springtime temperature differences and stratification diminish.

\subsection{Temperature and salinity fluctuations}

The seasonal sea-surface temperature (SST) variation describes a sinusoidal curve with a maximum mean of $22.3^{\circ} \mathrm{C}$ in September and a minimum mean of $15.6^{\circ} \mathrm{C}$ in March (Fig. 3a, Table 1). These values are in good accordance to the general SST curve for the Azores Archipelago compiled by Lafon et al. (2004) but the amplitude exhibits a pronounced two month offset with minimum values in March instead of January and a maximum in September instead of July, respectively. The reason for this offset remains enigmatic but could reflect a considerable inter-annual variability. The am- plitude and absolute values of the seasonal cyclicity decrease with depth until at the 150 and $500 \mathrm{~m}$ stations near-constant temperatures of $\sim 15^{\circ} \mathrm{C}$ and $\sim 12^{\circ} \mathrm{C}$, respectively, prevail.

Short-term temperature fluctuations at the 0 to $150 \mathrm{~m}$ stations are largely co-varying with the tidal rhythm with higher values logged during tidal low stands (Fig. 3b-c). According to Simões et al. (1997), the partly barotropic tidal current is directed to the north during flood tide and to the south during ebb tide with a maximum current speed of $1 \mathrm{~m} / \mathrm{s}$ in the centre of the channel. In autumn, the fluctuations are most pronounced at the $60 \mathrm{~m}$ station with strong shifts of up to $5^{\circ} \mathrm{C}$ within a few hours. This is illustrated in Fig. $3 \mathrm{~b}$ where 

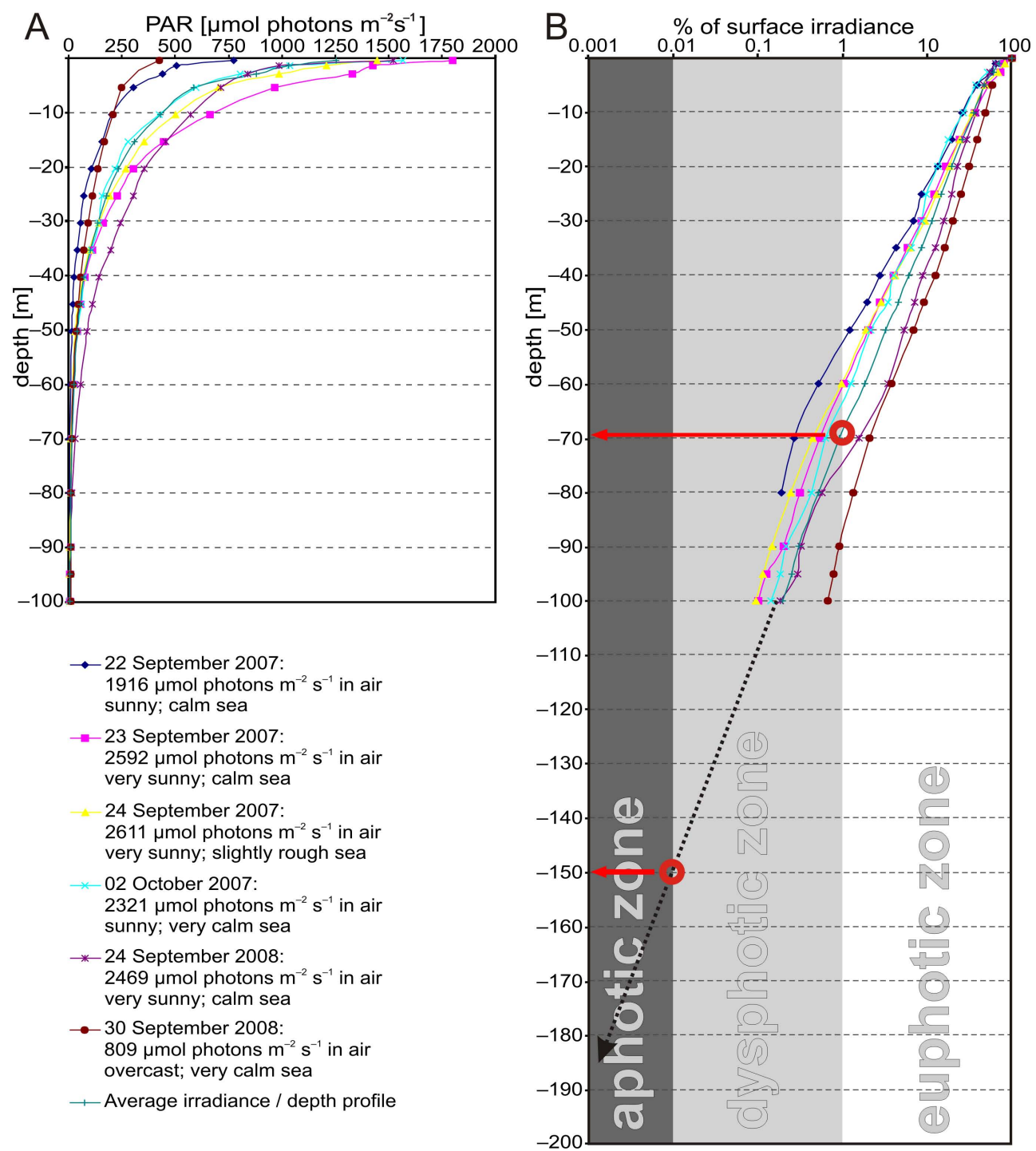

Fig. 4. Measurements of the photosynthetically active radiation (PAR; unit: $\mu$ mol photons $\mathrm{m}^{-2} \mathrm{~s}^{-1}$ ) with depth, carried out in the southern Faial Channel. (A) The irradiance exponentially decreases toward deeper waters. The surface irradiance in air, along with the weather conditions are given in the legend. (B) Semi-logarithmic plot of light intensities expressed as per cent of the surface irradiance measured just below the water surface, indicating a base of the euphotic zone (1\% surface irradiance) in an average $70 \mathrm{~m}$ of water depth and a base of the dysphotic zone $(\sim 0.01 \%$ surface irradiance) in $150 \mathrm{~m}$, respectively.

the hi-res record of one week in September 2006 around spring/neap-tide is plotted together with the tidal curve for Horta (computed via WXTide32 version 4.7). These strong fluctuations indicate a thermocline close to $60 \mathrm{~m}$ depth resulting in tidal-driven mixing and/or a vertical shifting of this boundary. This pattern reflects the autumn situation with the strongest temperature difference between the surface and intermediate water layers, whereas in the springtime temperatures converge and stratification diminishes. During low temperatures in March (Fig. 3c) the differences from surface waters down to $150 \mathrm{~m}$ water depth are minute and particularly the 60 and $150 \mathrm{~m}$ signal exhibit a near-perfect covariance that is negatively correlated with the tidal cycle. At the intertidal station, the data loggers emerged during low tides so that they were prone to cooling (e.g. during the first half of the week plotted in Fig. 3c). At $15 \mathrm{~m}$ water depth the tidal signal is low. At the $500 \mathrm{~m}$ station the same constant absolute temperature and tidal-independent moderate short-term fluctuations are seen for both seasonal end-members (Fig. 3b-c). In good accordance to these results, Santos et al. (1995) states, that during winter a deep mixed layer is present around $150 \mathrm{~m}$ and in summer a seasonal thermocline develops around 40 to $100 \mathrm{~m}$. 
Table 1. Bottom-water temperatures (given in ${ }^{\circ} \mathrm{C}$ as monthly and annual means $\pm \mathrm{SD}$, minimum, and maximum) logged via autonomous temperature loggers at the various experimental stations in $0,15,60,150$ and $500 \mathrm{~m}$ water depth.

\begin{tabular}{|c|c|c|c|c|c|c|c|c|c|c|c|c|c|}
\hline Depth & ct. & Nov. & Dec. & Jan. & Feb. & Mar. & Apr. & May & Jun. & Jul. & Aug. & Sep. & Total \\
\hline 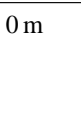 & $\begin{array}{l}.2 \pm 0.6 \\
\text { in } 18.0 \\
\text { ax } 21.8\end{array}$ & $\begin{array}{l}18.7 \pm 0.7 \\
\min 15.2 \\
\max 20.0\end{array}$ & $\begin{array}{l}16.8 \pm 0.6 \\
\min 13.4 \\
\max 17.8\end{array}$ & $\begin{array}{l}16.3 \pm 0.4 \\
\min 23.4 \\
\max 17.5\end{array}$ & $\begin{array}{l}16.0 \pm 0.5 \\
\min 13.2 \\
\max 16.8\end{array}$ & $\begin{array}{l}15.5 \pm 0.6 \\
\min 12.6 \\
\max 17.9\end{array}$ & $\begin{array}{l} \pm 0.6 \\
3.0 \\
18.9\end{array}$ & $\begin{array}{l}=0.8 \\
4.7 \\
6.4\end{array}$ & $\begin{array}{l}18.4 \\
\min \\
\max \end{array}$ & $\begin{array}{l}21.0 \pm 1.1 \\
\min 18.4 \\
\max 32.9\end{array}$ & $\begin{array}{l}=0.8 \\
9.5 \\
0.8\end{array}$ & $\begin{array}{l}=0.7 \\
9.9 \\
7.8\end{array}$ & $\begin{array}{l}18 . \\
\mathrm{min} \\
\mathrm{ma}\end{array}$ \\
\hline $15 \mathrm{~m}$ & $\begin{array}{l}20.2 \pm 0.7 \\
\min 18.0 \\
\max 21.6\end{array}$ & $\begin{array}{l}18.8 \pm 0.7 \\
\min 16.6 \\
\max 20.0\end{array}$ & $\begin{array}{l}17.0 \pm 0.3 \\
\min 16.2 \\
\max 17.6\end{array}$ & $\begin{array}{l}16.5 \pm 0.2 \\
\min 15.8 \\
\max 17.0\end{array}$ & $\begin{array}{l}16.0 \pm 0.3 \\
\min 14.4 \\
\max 16.6\end{array}$ & $\begin{array}{l}15.7 \pm 0.3 \\
\min 14.5 \\
\max 16.2\end{array}$ & $\begin{array}{l}16.0 \pm 0.3 \\
\min 15.1 \\
\max 16.7\end{array}$ & $\begin{array}{l}16.7 \pm 0.6 \\
\min 15.3 \\
\max 18.4\end{array}$ & $\begin{array}{l}17.8 \pm 0.7 \\
\min 15.8 \\
\max 19.3\end{array}$ & $\begin{array}{l}20.0 \pm 0.9 \\
\min 17.0 \\
\max 22.1\end{array}$ & $\begin{array}{l}21.0 \pm 1.2 \\
\min 17.5 \\
\max 23.0\end{array}$ & $\begin{array}{l}0.7 \\
8.3 \\
3.0\end{array}$ & $\begin{array}{l}18.1 \pm 0.7 \\
\min 14.4 \\
\max 23.0\end{array}$ \\
\hline 60 & $\begin{array}{l}18.2 \pm 1.1 \\
\min 15.4 \\
\max 20.8\end{array}$ & $\begin{array}{l}17.7 \pm 0.8 \\
\min 15.0 \\
\max 19.4\end{array}$ & $\begin{array}{l}16.6 \pm 0.5 \\
\min 14.9 \\
\max 17.6\end{array}$ & $\begin{array}{l}16.1 \pm 0.4 \\
\min 14.7 \\
\max 16.9\end{array}$ & $\begin{array}{l}15.6 \pm 0.6 \\
\min 13.8 \\
\max 16.5\end{array}$ & $\begin{array}{l}15.1 \pm 0.5 \\
\min 13.7 \\
\max 16.1\end{array}$ & $\begin{array}{l}15.3 \pm 0.4 \\
\min 14.2 \\
\max 16.4\end{array}$ & $\begin{array}{l}15.5 \pm 0.4 \\
\min 14.2 \\
\max 17.0\end{array}$ & $\begin{array}{l}16.2 \pm 0.7 \\
\min 14.6 \\
\max 18.3\end{array}$ & $\begin{array}{l}17.0 \pm 0.8 \\
\min 15.3 \\
\max 19.5\end{array}$ & $\begin{array}{l}17.3 \pm 1.4 \\
\min 14.9 \\
\max 21.6\end{array}$ & $\begin{array}{l}18.0 \pm 1.4 \\
\min 15.1 \\
\max 21.5\end{array}$ & $\begin{array}{l}16.5 \pm 0.8 \\
\min 13.7 \\
\max 21.6\end{array}$ \\
\hline & $\begin{array}{l}15.3 \pm 0.4 \\
\min 14.4 \\
\max 17.0\end{array}$ & $\begin{array}{l}15.1 \pm 0.5 \\
\min 13.6 \\
\max 17.8\end{array}$ & $\begin{array}{l}15.5 \pm 0.7 \\
\min 14.1 \\
\max 17.1\end{array}$ & $\begin{array}{l}15.5 \pm 0.6 \\
\min 13.9 \\
\max 16.7\end{array}$ & $\begin{array}{l}15.1 \pm 0.6 \\
\min 13.6 \\
\max 16.3\end{array}$ & $\begin{array}{l}14.7 \pm 0.5 \\
\min 13.5 \\
\max 15.8\end{array}$ & $\begin{array}{l}14.8 \pm 0.3 \\
\min 13.9 \\
\max 15.6\end{array}$ & $\begin{array}{l}14.8 \pm 0.3 \\
\min 13.9 \\
\max 15.7\end{array}$ & $\begin{array}{l}14.9 \pm 0.4 \\
\min 13.9 \\
\max 16.1\end{array}$ & $\begin{array}{l}15.1 \pm 0.3 \\
\min 14.2 \\
\max 16.6\end{array}$ & $\begin{array}{l}15.1 \pm 0.4 \\
\min 14.0 \\
\max 16.6\end{array}$ & $\begin{array}{l}15.1 \pm 0.4 \\
\min 14.3 \\
\max 17.9\end{array}$ & $\begin{array}{l}15.1 \pm 0.5 \\
\min 13.5 \\
\max 17.9\end{array}$ \\
\hline $500 \mathrm{~m}$ & $\begin{array}{l}12.4 \pm 0.3 \\
\min 11.3 \\
\max 13.4\end{array}$ & $\begin{array}{l}12.2 \pm 0.3 \\
\min 10.9 \\
\max 13.1\end{array}$ & $\begin{array}{l}12.2 \pm 0.3 \\
\min 11.4 \\
\max 13.4\end{array}$ & $\begin{array}{l}12.3 \pm 0.2 \\
\min 11.1 \\
\max 13.1\end{array}$ & $\begin{array}{l}12.1 \pm 0.3 \\
\min 11.0 \\
\max 13.1\end{array}$ & $\begin{array}{l}12.1 \pm 0.2 \\
\min 11.1 \\
\max 12.9\end{array}$ & $\begin{array}{l}12.2 \pm 0.3 \\
\min 11.0 \\
\max 13.1\end{array}$ & $\begin{array}{l}12.3 \pm 0.2 \\
\min 11.2 \\
\max 13.0\end{array}$ & $\begin{array}{l}12.5 \pm 0.2 \\
\min 11.5 \\
\max 13.5\end{array}$ & $\begin{array}{l}12.5 \pm 0.2 \\
\min 11.7 \\
\max 13.1\end{array}$ & $\begin{array}{l}12.5 \pm 0.2 \\
\min 11.6 \\
\max 13.4\end{array}$ & $\begin{array}{l}12.3 \pm 0.3 \\
\min 11.3 \\
\max 13.3\end{array}$ & $\begin{array}{l}12.3 \pm 0.3 \\
\min 10.9 \\
\max 13.5\end{array}$ \\
\hline
\end{tabular}

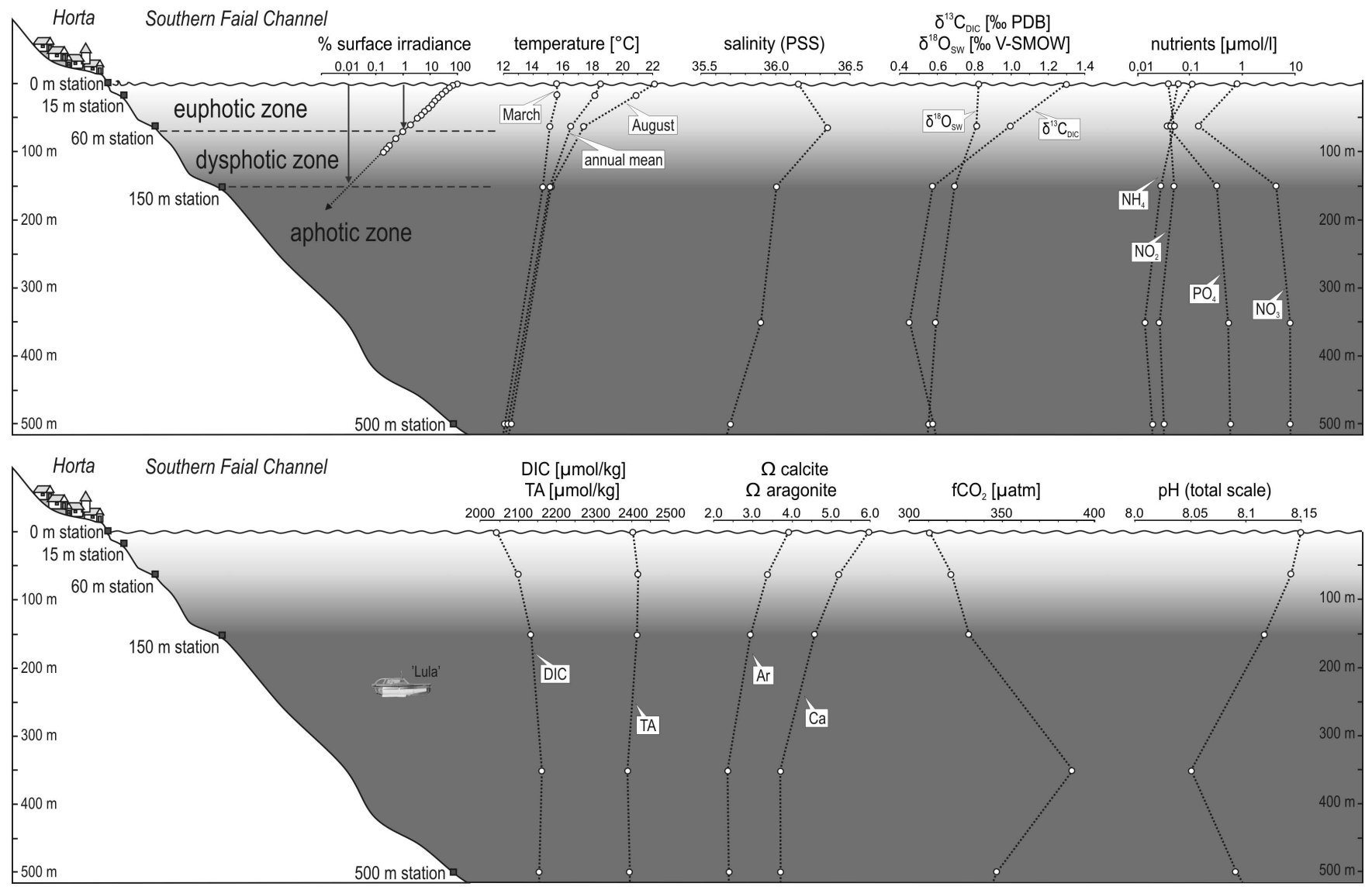

Fig. 5. Schematic bathymetric transect down-slope in the southern Faial Channel with the logged environmental parameters with regard to the light regime, temperature, salinity, stable $\mathrm{O}$ and $\mathrm{C}$ signature and nutrient regime (top), as well as the measured and computed carbonate system variables, total dissolved inorganic carbon, total alkalinity, saturation states for calcite and aragonite, $\mathrm{CO}_{2}$ fugacity, and $\mathrm{pH}$ (bottom). 
As noted above, the salinity loggers largely failed to meet their specifications during the 2-year exposure period, yielding only few months of usable data. At $60 \mathrm{~m}$, the one-month period from 21 October through 20 November 2006 has a mean salinity of $36.3 \pm 0.2$ and at the $500 \mathrm{~m}$ station, the seven-month period from 7 November 2006 through 6 July 2007 a mean salinity of $35.3 \pm 0.1$, respectively. The values measured in the water samples (Table 2; Fig. 5) slightly decrease with depth from a 36.35 mean at $60 \mathrm{~m}$ to 35.70 at $500 \mathrm{~m}$. Both data sets indicate a general slight decrease in salinity towards deeper waters.

\subsection{Light regime}

Light irradiance in relation to water depth is a main factor influencing the distribution of photoautotrophic biota and their contribution to carbonate accretion by crustose algae, and carbonate degradation by endolithic chlorophytes and cyanobacteria (Schlager, 2003, 2005; Golubic et al., 1975). The scheme of the photic zonation distinguishes a euphotic, a dysphotic, and an aphotic zone. The base of the euphotic zone is the depth where the intensity of the photosynthetic active radiation (PAR) declines to $1 \%$ of the surface irradiance and roughly equates to the photic limit where photosynthesis balances respiration. The base of the dysphotic zone below which photoautotrophs can't exist is found at $\sim 0.01 \%$ (e.g. Glaub, 1994).

For the seven depth-PAR profiles logged in September 2007 and 2008 in the southern Faial Channel, the surface irradiance ranged from 809 to $2611 \mu \mathrm{mol}$ photons $\mathrm{m}^{-2} \mathrm{~s}^{-1}$ above, and 419 to $1797 \mu$ mol photons $\mathrm{m}^{-2} \mathrm{~s}^{-1}$ just below the sea surface (Fig. 4a). The light levels decreased exponentially with depth (Fig. 4a-b), except for an elevated decrease in the uppermost $\sim 5 \mathrm{~m}$ of the water column with a strong absorption for long-wave radiation, a typical feature of quanta irradiance profiles (Jerlov, 1976). The base of the euphotic zone was observed at 50 to $90 \mathrm{~m}$ depth with an average of $70 \mathrm{~m}$. The base of the dysphotic zone was estimated by projecting the mean light/depth profile in the semi-logarithmic graph towards deeper waters, which intersects the $0.01 \%$ boundary at $150 \mathrm{~m}$ depth (Fig. 4b). The validity of this extrapolation is warranted by an optically sufficiently homogenous water column, as confirmed by Piazena et al. (2002) in an extensive study of the light regime with respect to the wavelength dependant penetration of solar radiation south of the Azores.

Following the present zonation pattern, the light regime in the southern Faial Channel can be classified as optical water types II to IB in the Jerlov classification (Jerlov, 1968, 1976). This is in good accordance with the map of regional distribution of optical water types given by Jerlov (1976: figure 72) as well as to the PAR profiles logged by Piazena et al. (2002) just south of the Azores. There, the latter authors found a maximum chlorophyll a concentration around the $1 \%$ sub-surface irradiance level, demonstrating effective photosynthesis utilising short-wave radiation in the deep euphotic and upper dysphotic zone. The presence of such a deep chlorophyll maximum (DCM) in around $100 \mathrm{~m}$ depth was also confirmed for the Azores Front region (Fasham et al., 1985; Lorenzo et al., 2004).

\subsection{Seawater stable isotope signature}

The seawater $\delta^{18} \mathrm{O}_{\mathrm{sw}}$ oxygen isotope ratio (Table 2; Fig. 5) steadily decreases with depth from $0.82 \pm 0.01 \%$ at the sea surface down to $0.55 \pm 0.07 \%$ V-SMOW at $500 \mathrm{~m}$ depth. The stable carbon isotope signal of dissolved inorganic carbon $\left({ }^{13} \mathrm{C}_{\mathrm{DIC}}\right)$ likewise decreases with depth from a maximum of $1.30 \pm 0.06 \%$ in surface waters to $0.57 \pm 0.13 \%$ o PDB at the $500 \mathrm{~m}$ station, but the lowest values were found at $350 \mathrm{~m}(0.45 \pm 0.05 \%$ o PDB $)$. The percentaged standard deviations as a measure of relative fluctuations of both parameters generally increase with depth with variations roughly twice as pronounced for $\delta^{13} \mathrm{C}_{\mathrm{DIC}}$ if compared to $\delta^{18} \mathrm{O}_{\mathrm{sw}}$.

Water stable isotope assessments are scarce for the central parts of the Atlantic and there are no records at all listed for the Azores Archipelago in the current version 1.19 of the NASA GISS Global Seawater $\delta^{18} \mathrm{O}_{\mathrm{sw}}$ Database (Schmidt et al., 1999; Bigg and Rohling, 2000). Nevertheless, these measurements are indispensable for calculating temperature-related expected equilibrium isotope compositions in calcareous skeletons and to evaluate their vital effects, as undertaken for instance with the present $500 \mathrm{~m}$ data for the deep-sea oyster Neopycnodonte zibrowii by Wisshak et al. (2009c), the stylasterid hydrocoral Errina dabneyi by Wisshak et al. (2009a), and solitary scleractinians by Marali et al. (2009).

When comparing the present Azores stable isotope data with the gridded data set of the global $\delta^{18} \mathrm{O}_{\mathrm{sw}}$ of sea surface waters (LeGrande and Schmidt, 2006: figure 1) the $\delta^{18} \mathrm{O}_{\mathrm{sw}}$ value of the $0 \mathrm{~m}$ station fits well into this interpolation. Likewise the $\delta^{18} \mathrm{O}_{\mathrm{sw}}$ values from the deeper stations are in good accordance to the distinct decrease towards deeper waters in the central Atlantic as demonstrated by the same authors (LeGrande and Schmidt, 2006: figure 2).

\subsection{Nutrient distribution}

The nutrient composition (Table 2) of the ambient seawater was characterised with respect to nitrate $\left(\mathrm{NO}_{3}^{-}\right)$, nitrite $\left(\mathrm{NO}_{2}^{-}\right)$, ammonium $\left(\mathrm{NH}_{4}^{+}\right)$and phosphate $\left(\mathrm{PO}_{4}^{3-}\right)$. While nitrate and phosphate increase with depth below a minimum at the $60 \mathrm{~m}$ station, nitrite and ammonium have very low concentrations of less than $0.06 \mu \mathrm{mol} / \mathrm{l}$ and tentatively decrease with depth. Nitrate concentration is low in surface waters $(0.8 \mu \mathrm{mol} / \mathrm{l})$ and peaks at $7.98 \pm 1.11 \mu \mathrm{mol} / \mathrm{l}$ in $500 \mathrm{~m}$ depth. Correspondingly the phosphate level increases from only 0.12 to $0.59 \pm 0.16 \mu \mathrm{mol} / \mathrm{l}$ at the $500 \mathrm{~m}$ station. Redfield $\mathrm{N}: \mathrm{P}$ ratios range from 6.0 to 14.8 at the $60 \mathrm{~m}$ and $350 \mathrm{~m}$ 
Table 2. Summary of measured water property data, as there are the stable isotope signature, salinity, total alkalinity, total dissolved inorganic carbon, nitrate $\left(\mathrm{NO}_{3}^{-}\right)$, nitrite $\left(\mathrm{NO}_{2}^{-}\right)$, ammonium $\left(\mathrm{NH}_{4}^{+}\right)$and phosphate $\left(\mathrm{PO}_{4}^{3-}\right)$. Mean values are given per depth station together with the absolute and percentaged standard deviation.

\begin{tabular}{llllllllll}
\hline Depth station/n & $\begin{array}{l}\delta^{18} \mathrm{O}_{\mathrm{SW}} \\
{[\% \circ \mathrm{V}-\mathrm{SMOW}]}\end{array}$ & $\begin{array}{l}\delta^{13} \mathrm{C}_{\mathrm{DIC}} \\
{[\% \text { PDB }]}\end{array}$ & $\begin{array}{l}\text { Salinity } \\
(\mathrm{PSS})\end{array}$ & $\begin{array}{l}\mathrm{TA} \\
{[\mu \mathrm{mol} / \mathrm{kg}]}\end{array}$ & $\begin{array}{l}\mathrm{DIC} \\
{[\mu \mathrm{mol} / \mathrm{kg}]}\end{array}$ & $\begin{array}{l}\mathrm{NO}_{3}^{-} \\
{[\mu \mathrm{mol} / 1]}\end{array}$ & $\begin{array}{l}\mathrm{NO}_{2}^{-} \\
{[\mu \mathrm{mol} / 1]}\end{array}$ & $\begin{array}{l}\mathrm{NH}_{4}^{+} \\
{[\mu \mathrm{mol} / 1]}\end{array}$ & $\begin{array}{l}\mathrm{PO}_{4}^{3-} \\
{[\mu \mathrm{mol} / 1]}\end{array}$ \\
\hline $0 \mathrm{~m}(n=1)$ & 0.82 & 1.30 & 36.15 & 2401.42 & 2045.53 & 0.80 & 0.06 & 0.04 & 0.12 \\
$\mathrm{SD}$ & \pm 0.01 & \pm 0.06 & \pm 0.07 & \pm 0.13 & - & - & - & - & - \\
$\mathrm{SD} \%$ & 0.87 & 4.91 & 0.20 & 0.01 & - & - & - & - & - \\
$60 \mathrm{~m}(n=2)$ & 0.81 & 0.99 & 36.35 & 2414.25 & 2101.38 & 0.15 & 0.04 & 0.05 & 0.04 \\
$\mathrm{SD}$ & \pm 0.06 & \pm 0.13 & \pm 0.17 & \pm 5.59 & \pm 20.96 & \pm 0.04 & \pm 0.00 & \pm 0.05 & \pm 0.00 \\
$\mathrm{SD} \%$ & 7.35 & 13.40 & 0.48 & 0.23 & 1.00 & 27.39 & 8.63 & 93.88 & 0.00 \\
$150 \mathrm{~m}(n=2)$ & 0.69 & 0.57 & 36.00 & 2413.32 & 2135.64 & 4.35 & 0.05 & 0.03 & 0.32 \\
$\mathrm{SD}$ & \pm 0.03 & \pm 0.07 & \pm 0.08 & \pm 16.84 & \pm 13.69 & \pm 1.27 & \pm 0.01 & \pm 0.02 & \pm 0.01 \\
$\mathrm{SD} \%$ & 4.95 & 11.66 & 0.23 & 0.70 & 0.64 & 29.12 & 14.58 & 84.21 & 2.11 \\
$350 \mathrm{~m}(n=2)$ & 0.59 & 0.45 & 35.90 & 2385.22 & 2156.75 & 7.95 & 0.03 & 0.01 & 0.54 \\
$\mathrm{SD}$ & \pm 0.04 & \pm 0.05 & \pm 0.00 & \pm 4.39 & \pm 9.03 & \pm 1.37 & \pm 0.00 & \pm 0.00 & \pm 0.09 \\
$\mathrm{SD} \%$ & 6.95 & 11.17 & 0.00 & 0.18 & 0.42 & 17.18 & 13.61 & 27.86 & 16.25 \\
$500 \mathrm{~m}(n=4)$ & 0.55 & 0.57 & 35.70 & 2391.59 & 2151.47 & 7.98 & 0.03 & 0.02 & 0.59 \\
$\mathrm{SD}$ & \pm 0.07 & \pm 0.13 & \pm 0.12 & \pm 5.04 & \pm 17.15 & \pm 1.11 & \pm 0.01 & \pm 0.01 & \pm 0.16 \\
$\mathrm{SD} \%$ & 12.48 & 23.51 & 0.32 & 0.21 & 0.80 & 13.91 & 20.83 & 28.26 & 27.11 \\
\hline
\end{tabular}

station, respectively, indicating a nitrogen limitation due to planktonic primary production in the surface water and remineralisation towards balanced Redfield ratios in deeper waters (Redfield et al., 1963). Interestingly, the nutrient depletion was highest at the $60 \mathrm{~m}$ station, providing further evidence for the presence of a DCM (see above). This trophic regime represents the autumn situation and does not account for the seasonal variation, which is characteristic for temperate and polar environments.

\subsection{Assessing the carbonate system}

Total alkalinity (TA) decreases with depth to $2391.59 \pm 5.04 \mu \mathrm{mol} / \mathrm{kg}$ at $500 \mathrm{~m}$, below a maximum of $2414.25 \pm 5.59 \mu \mathrm{mol} / \mathrm{kg}$ at the $60 \mathrm{~m}$ station, while dissolved inorganic carbon (DIC) increases (Table 3) from $2045.53 \mu \mathrm{mol} / \mathrm{kg}$ in the surface water to $2151.47 \pm 17.15$ at the $500 \mathrm{~m}$ station. Calculated carbonate system parameters for $\mathrm{fCO}_{2}, \mathrm{pH}$ and calcium carbonate $\left(\mathrm{CaCO}_{3}\right)$ mineral saturation states for calcite $\left(\Omega_{\mathrm{Ca}}\right)$ and aragonite $\left(\Omega_{\mathrm{Ar}}\right)$ show a consistent depth profile: High photosynthetic activity leads to relatively low $\mathrm{fCO}_{2}$ concentrations in the surface waters $(310.29 \mu \mathrm{atm})$ while concentration increase with depth due to less primary production and cooler temperatures. Corresponding saturation states decrease with water depth to values of $\Omega_{\mathrm{Ca}}=3.72 \pm 0.17$ and $\Omega_{\mathrm{Ar}}=2.39 \pm 0.11$ at $500 \mathrm{~m}$. Although lower saturation states are suggested to reduce benthic calcification rates (Langdon et al., 2000; Marubini et al., 2002; see Doney et al., 2009 for review) and to favour bioerosion (Manzello et al., 2008), the measured states are fairly supersaturated and within natural limits.

\subsection{Carbonate bioerosion and accretion rates}

Absolute values of the experimentally determined carbonate bioerosion rates (Fig. 6a-b, e) decrease rapidly with water depth. Bioerosion is strongest in the intertidal zone where the mean bioerosion rates reach $-456 \pm 144$ and $-631 \pm 82 \mathrm{~g} / \mathrm{m}^{2} / \mathrm{yr}$ after one and two years of exposure, respectively. The weakest rates were found in aphotic depths were only few grams of carbonate for the most were degraded per square metre and year. The overall bioerosion rates, considering both exposure periods and orientations, show the same bathymetrical pattern. In the reach of photoactive light irradiation at the 15 and $60 \mathrm{~m}$ stations, bioerosion was found to be about tenfold stronger on the up-facing versus the down-facing substrates. Bioerosion decreased with increasing exposure time, with the most prominent exception being the intertidal, where bioerosion rates remained stable.

The bathymetrical decrease of bioerosion is primarily linked to the availability of light as energy source for phototrophic microborers (cyanobacteria, chlorophytes, rhodophytes) and the linked effect of intensified grazing upon them (patellids, chitons, echinoids). The bathymetrical pattern is in good agreement with previous experimental studies (e.g. Hoskin et al., 1986; Hassan, 1998; Vogel et al., 1996, 2000; see Wisshak, 2006 for a review) as well as qualitative assessments of bioeroding communities (e.g. Golubic et al., 1975; Zeff and Perkins, 1979; Budd and Perkins, 1980; Wisshak et al., 2005). Light also governs the differential bioerosion rates of the directly illuminated up-facing orientation compared to the shaded down-facing substrates. The 
1 year bioerosion rates $\left[\mathrm{g} / \mathrm{m}^{2} / \mathrm{yr}\right]$

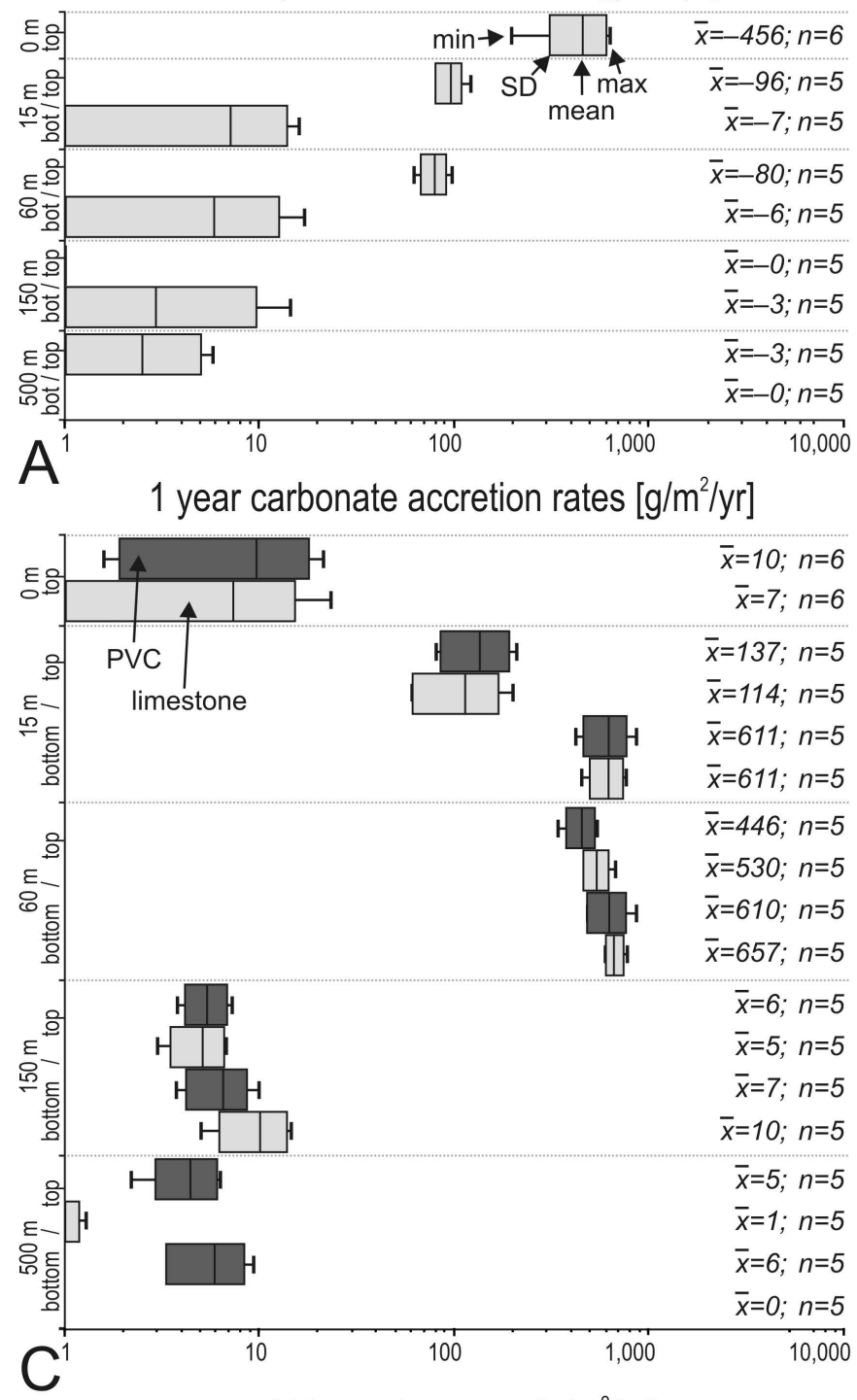

total bioerosion rates $\left[\mathrm{g} / \mathrm{m}^{2} / \mathrm{yr}\right]$

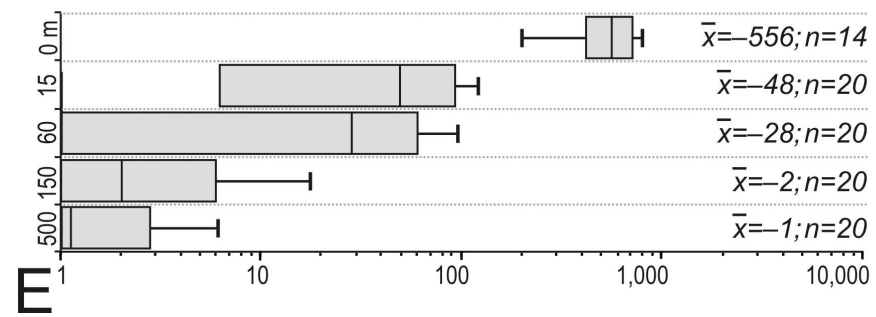

2 year bioerosion rates $\left[\mathrm{g} / \mathrm{m}^{2} / \mathrm{yr}\right]$
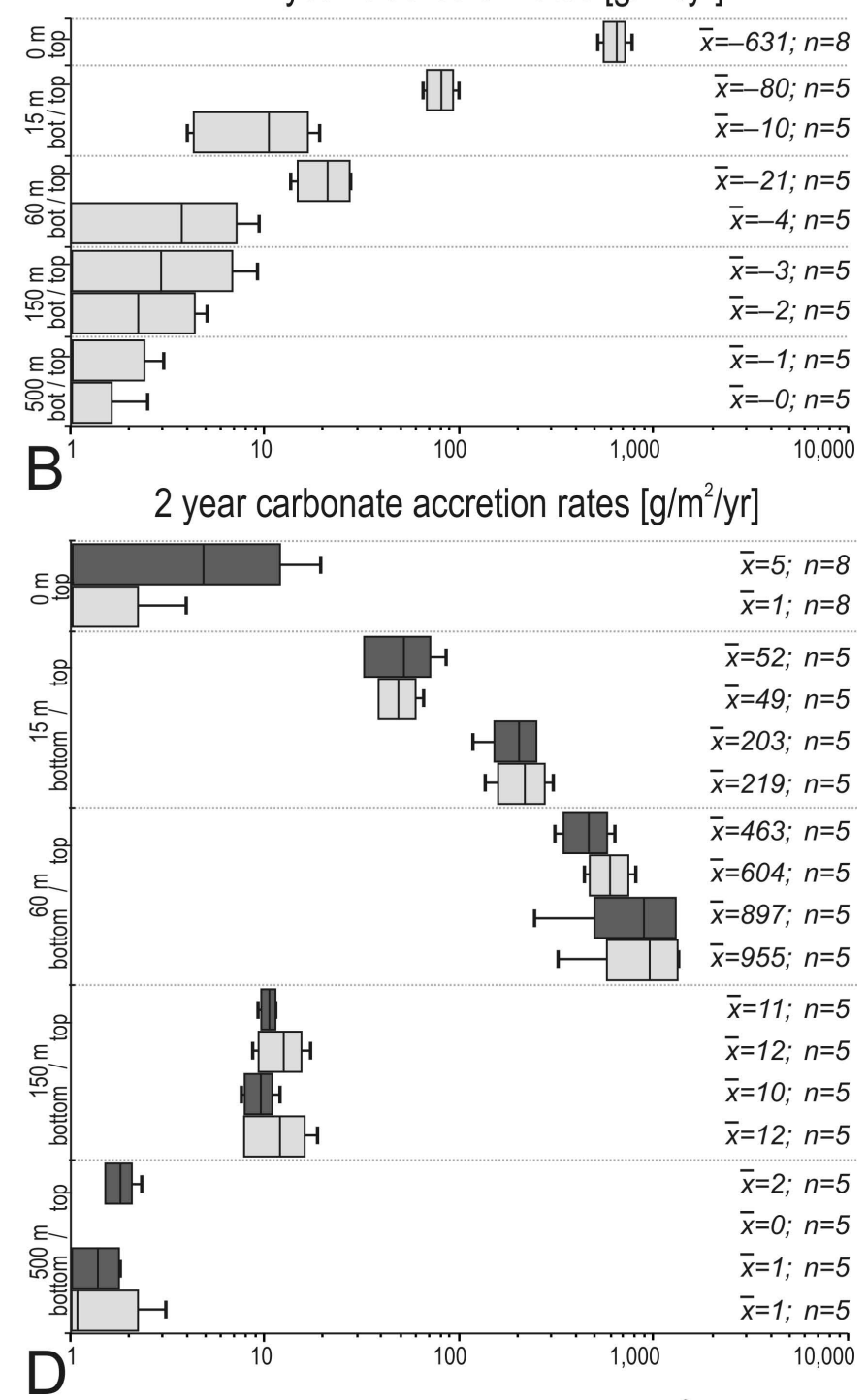

total carbonate accretion rates $\left[\mathrm{g} / \mathrm{m}^{2} / \mathrm{yr}\right]$

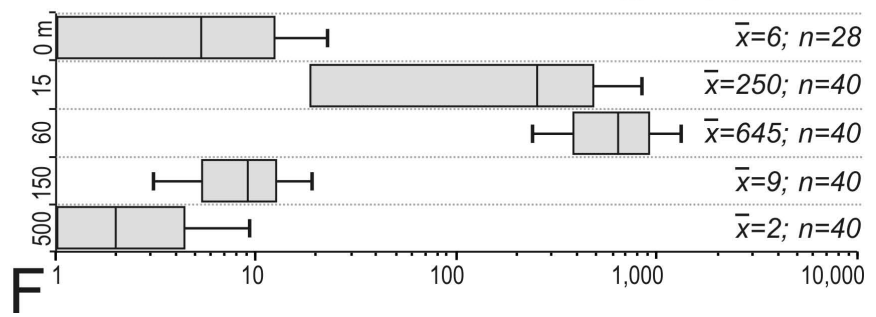

Fig. 6. Logarithmic plots showing mean values, SD, $\min / \mathrm{max}$ and number of replicates of carbonate accretion and bioerosion rates in grams per square metre and year, gravimetrically determined via up- and down-facing limestone and PVC settlement plates on experimental frames in the southern Faial Channel in 0, 15, 60, 150, and $500 \mathrm{~m}$ of water depth. (A-B) One and two year bioerosion rates. (C-D) One and two year carbonate accretion rates differentiated by substrate orientation and type. (E) Total carbonate bioerosion rates for combined orientations and exposure times. (F) Total carbonate accretion rates for combined substrate types, orientations, and exposure times. 
Table 3. Computed carbonate system parameters ( $\mathrm{pH}$, fugacity, and saturation states for calcite and aragonite) based on the given measurements of temperature, salinity, total alkalinity and total dissolved inorganic carbon. Mean values are given per depth station together with the absolute and percentaged standard deviation.

\begin{tabular}{lllllllll}
\hline Depth station/n & $\begin{array}{l}\text { temp } \\
{\left[{ }^{\circ} \mathrm{C}\right]}\end{array}$ & $\begin{array}{l}\text { Salinity } \\
(\mathrm{PSS})\end{array}$ & $\begin{array}{l}\mathrm{TA} \\
{[\mu \mathrm{mol} / \mathrm{kg}]}\end{array}$ & $\begin{array}{l}\mathrm{DIC} \\
{[\mu \mathrm{mol} / \mathrm{kg}]}\end{array}$ & $\begin{array}{l}\mathrm{pH} \\
(\text { total scale) }\end{array}$ & $\begin{array}{l}\mathrm{fCO}_{2} \\
{[\mu \mathrm{atm}]}\end{array}$ & $\Omega_{\mathrm{Ca}}$ & $\Omega_{\mathrm{Ar}}$ \\
\hline $0 \mathrm{~m}(n=1)$ & 22.26 & 36.15 & 2401.42 & 2045.53 & 8.15 & 310.29 & 5.97 & 3.91 \\
$\mathrm{SD}$ & - & \pm 0.07 & \pm 0.13 & - & - & - & - & - \\
$\mathrm{SD} \%$ & - & 0.20 & 0.01 & - & - & - & - & - \\
$60 \mathrm{~m}(n=2)$ & 18.03 & 36.35 & 2414.25 & 2101.38 & 8.14 & 321.68 & 5.19 & 3.37 \\
$\mathrm{SD}$ & - & \pm 0.17 & \pm 6.57 & \pm 20.96 & \pm 0.03 & \pm 25.04 & \pm 0.23 & \pm 0.15 \\
$\mathrm{SD} \%$ & - & 0.48 & 0.27 & 1.00 & 0.33 & 7.78 & 4.36 & 4.34 \\
$150 \mathrm{~m}(n=2)$ & 15.10 & 36.00 & 2413.32 & 2135.64 & 8.12 & 331.39 & 4.57 & 2.94 \\
$\mathrm{SD}$ & - & \pm 0.08 & \pm 20.62 & \pm 13.69 & \pm 0.01 & \pm 4.98 & \pm 0.11 & \pm 0.07 \\
$\mathrm{SD} \%$ & - & 0.23 & 0.85 & 0.64 & 0.10 & 1.50 & 2.51 & 2.52 \\
$350 \mathrm{~m}(n=2)$ & 13.52 & 35.90 & 2385.22 & 2156.75 & 8.05 & 387.65 & 3.67 & 2.36 \\
$\mathrm{SD}$ & - & \pm 0.00 & \pm 5.27 & \pm 9.03 & \pm 0.01 & \pm 9.37 & \pm 0.05 & \pm 0.03 \\
$\mathrm{SD} \%$ & - & 0.00 & 0.22 & 0.42 & 0.10 & 2.42 & 1.32 & 1.32 \\
$500 \mathrm{~m}(n=4)$ & 12.34 & 35.70 & 2391.59 & 2151.47 & 8.09 & 346.91 & 3.72 & 2.39 \\
$\mathrm{SD}$ & - & \pm 0.12 & \pm 5.33 & \pm 17.15 & \pm 0.02 & \pm 22.91 & \pm 0.17 & \pm 0.11 \\
$\mathrm{SD} \%$ & - & 0.32 & 0.22 & 0.80 & 0.30 & 6.62 & 4.51 & 4.53 \\
\hline
\end{tabular}

difference in bioerosion between these two orientations was quantified herein for the first time and turns out to be about tenfold in magnitude in the shallow and deep euphotic stations $(15$ and $60 \mathrm{~m})$ and diminishing at the dysphotic station $(150 \mathrm{~m})$. This difference is somewhat exaggerated by the higher density of epilithobionts on the downward orientation which reduces the pristine experimental substrate availability for bioerosion agents. The pattern of a decrease in bioerosion with time is in good accordance to the experimental results from the Swedish Kosterfjord (Wisshak, 2006), with the very same exception that at the shallowest station bioerosion increased with time.

As for the carbonate accretion rates (Fig. $6 \mathrm{c}-\mathrm{d}$, f), the highest rates were not encountered in the intertidal but at the $15 \mathrm{~m}$ and particularly at the $60 \mathrm{~m}$ station where the substrate is less subjected to hydrodynamic force. The determined rates peak after two years of exposure at mean values of $897 \pm 410$ and $955 \pm 380 \mathrm{~g} / \mathrm{m}^{2} / \mathrm{yr}$ for down-facing PVC and limestone substrate, respectively. Below this depth station, the accretion rates strongly decrease and at the aphotic $500 \mathrm{~m}$ station only few grams of carbonate for the most were built up per square metre and year. This bathymetrical pattern is also well expressed in the overall carbonate accretion rates where all exposure periods, orientations, and substrate types are considered. Concerning the substrate orientation, an inverse pattern from the carbonate bioerosion rates is evident, with carbonate accretion rates at the photic 15 and $60 \mathrm{~m}$ stations being considerably higher on the down-facing versus the up-facing substrates and a diminishing difference towards deeper waters. With respect to the substrate type, the differ- ences between PVC and limestone substrate are very small except for the intertidal zone with a higher rate of accretion on the PVC substrates which were not subjected to the pronounced bioerosion. The heterogeneity in the very low values at the $500 \mathrm{~m}$ station may be considered biased by a stronger methodological error where the relative error that is potentially introduced by accidental weight loss or gain due to the handling of the plates and platforms is larger, whereas this factor can be neglected where more carbonate was accreted and/or bioeroded.

Light as energy source could also be an important factor for the carbonate accretion by governing for instance the distribution and abundance of calcareous algae. The relative contribution of crustose algae to the present accretion rates is, however, very low and by far outcompeted by the rapid growth of serpulid worms (chiefly the large Spirobranchus polytrema), cirripeds (Chtalamus stellatus and Verruca spengleri), various bryozoan species, and particularly the oyster Neopycnodonte cochlear, the latter one being responsible for the highest bioaccretion rates encountered at the $60 \mathrm{~m}$ station. In the aphotic deeper water masses, carbonate accretion is very slow and epibenthic communities take many years to mature. Indeed, long-lived taxa, like deep-sea oysters (Wisshak et al., 2009c), hydrocorals (Wisshak et al., 2009a), scleractinians (e.g. Adkins et al., 2004) and isidid octocorals (Matsumoto, 2009), may be important (accretionary) carbonate producers on decadal to centennial timescales. 
A conspicuous pattern is the inverse trend developed for bioerosion and accretion rates when comparing the two substrate orientations (Fig. 6a-d). This suggests that bioerosion represents an important factor for governing the preferential settlement and growth of calcareous epilithobionts on down-facing substrates with a significantly lower bioerosion pressure, adding to the commonly referred factors of shading, negative phototactic larval behaviour, lower predation pressure, lower competition with epiphytes, and avoidance of sediment smothering (e.g. Crisp, 1974; Harris and Irons, 1986; Wendt et al., 1989; Connell, 1999; Glasby, 2000). Bioerosion has a direct negative effect on carbonate secreting epibionts by weakening their shell stability and the solidity of attachment to the substrate, both making them more susceptible to hydrodynamic force as well as predation. An indirect negative effect is seen in the enhanced grazing pressure where phototrophic microendoliths are more abundant, possibly leading to injury or even detachment of the epiliths and additionally affecting the success of larval settlement.

\subsection{Latitudinal gradient}

Putting the Azores carbonate bioerosion and accretion rates in context of a latitudinal and environmental gradient (Fig. 7) - roughly following the course of the Gulf Stream - there are three studies that allow for a semi-direct comparison. These are the experiments in the cold-temperate Swedish Kosterfjord in $59^{\circ}$ northern latitude (Wisshak et al., 2005, Wisshak, 2006) on the one hand and the studies on the tropical Bahamas $\left(26^{\circ} \mathrm{N}\right)$ carried out by Hoskin et al. (1986) and Vogel et al. $(1996,2000)$ on the other. These experiments applied a similar experimental design with respect to the utilised micritic limestone as substrate, a similar gravimetrical approach for determining the rates (except for Vogel et al., 1996, 2000, who used SEM surveys for quantifying bioerosion), and the investigation over an extended bathymetrical range. Additional data on carbonate production and degradation, but limited to a shallow water reef, were provided by Stearn et al. (1977) and Scoffin et al. (1980) for a fringing reef on Barbados, further extending the diagonal transatlantic transect to equatorial $13^{\circ} \mathrm{N}$.

In the cold-temperate waters of the Swedish Kosterfjord (Fig. 7 left) absolute values of bioerosion rates (equivalent methodology but limited to up-facing substrates) are about two to three times lower than in the Azores with values reaching a maximum of $-144 \mathrm{~g} / \mathrm{m}^{2} / \mathrm{yr}$ in $1 \mathrm{~m}$ water depth in a wave exposed setting, rapidly declining to values of only few tens of grams per square metre and year in deeper waters. Carbonate accretion is much weaker with only few grams for the most of carbonate produced per square metre and year, except for the shallowest station where balanids built up $362 \mathrm{~g} / \mathrm{m}^{2} / \mathrm{yr}$.

In the tropical Bahamas setting (Fig. 7 right), Hoskin determined microbioerosion rates of $-259,-237,-40,-2$ and $-0.5 \mathrm{~g} / \mathrm{m}^{2} / \mathrm{yr}$ after one year in $0,2,32,79$, and $477 \mathrm{~m}$ of water depth, respectively (figure 4 in Hoskin et al., 1986), and Vogel et al. found an average $-210,-105,-13,-6$, and $-2 \mathrm{~g} / \mathrm{m}^{2} / \mathrm{yr}$ combining one and two years of exposure in 2, 30, 100, 150 and $275 \mathrm{~m}$ depth (figure 7 in Vogel et al., 2000). In addition, Hoskin et al. (1986) determined grazing rates of specific grazers such as the chiton Acanthopleura granula which degrades about $-100 \mathrm{~g} / \mathrm{m}^{2} / \mathrm{yr}$ and the echinoid Echinometra lacunter reaching the impressive value of $-6670 \mathrm{~g} / \mathrm{m}^{2} / \mathrm{yr}$, indicating that the overall bioerosion at least for the shallowest waters in this tropical setting is probably far stronger than found in the Azores. This is also indicated by most bioerosion experiments carried out in the other warm-water coral provinces were total bioerosion rates - particularly governed by grazing echinoids and parrot fish - are usually in the range of -500 to $-10000 \mathrm{~g} / \mathrm{m}^{2} / \mathrm{yr}$ (see Table 1 in Wisshak, 2006 for a compilation of available experimental data).

From the tropical Caribbean, Stearn et al. (1977) presented a multifactorial analysis considering growth rates of various coral species and crustose algae, their relative abundance, as well as three-dimensional surface geometry, and determined a total carbonate production of $9000 \mathrm{~g} / \mathrm{m}^{2} / \mathrm{yr}$ for a Barbados fringing reef. Scoffin et al. (1980) complemented this study by quantifying carbonate degradation by macroborers and grazers in the same reef and found $-34 \mathrm{~g} / \mathrm{m}^{2} / \mathrm{yr}$ for parrot fish, $-5300 \mathrm{~g} / \mathrm{m}^{2} / \mathrm{yr}$ for the echinoid Diadema antillarum, and between -102 and $-507 \mathrm{~g} / \mathrm{m}^{2} / \mathrm{yr}$ bioerosion by macroborers in various coral and algae species. The gross carbonate production in the reef was found to be $68 \%$ higher than the carbonate degradation. These studies were, however, limited to the uppermost few metres of the water column and data for an extended bathymetrical transect in the Caribbean are not available at present.

\subsection{Carbonate budget}

A schematic summary of processes as well as principal organism groups involved in carbonate production and degradation in the Azores carbonate factory is given in Fig. 8, in relation to bathymetry, hydrodynamic force, and the photic zonation. The overwhelming majority of carbonate production is taking place in the photic zone above $150 \mathrm{~m}$ of water depth and is a combination of epilithic growth, such as quantified with the present experiment, and skeletal growth of mobile epi- and endobenthos. Typically for a $\mathrm{C}$ factory, carbonate production is almost exclusively biotically controlled by heterotrophs (Schlager, 2003), so that abiotic precipitation as well as biotically induced precipitation can be neglected in the present case. Carbonate degradation is by far most effective in the shallow euphotic zone where light promotes phototrophic bioerosion agents (cyanobacteria, chlorophytes) and grazers feeding upon them (gastropods, monoplacophorans, echinoids). An additional component is the physical erosion by hydrodynamic force above the storm wave base, which devastated the $5 \mathrm{~m}$ platforms and 


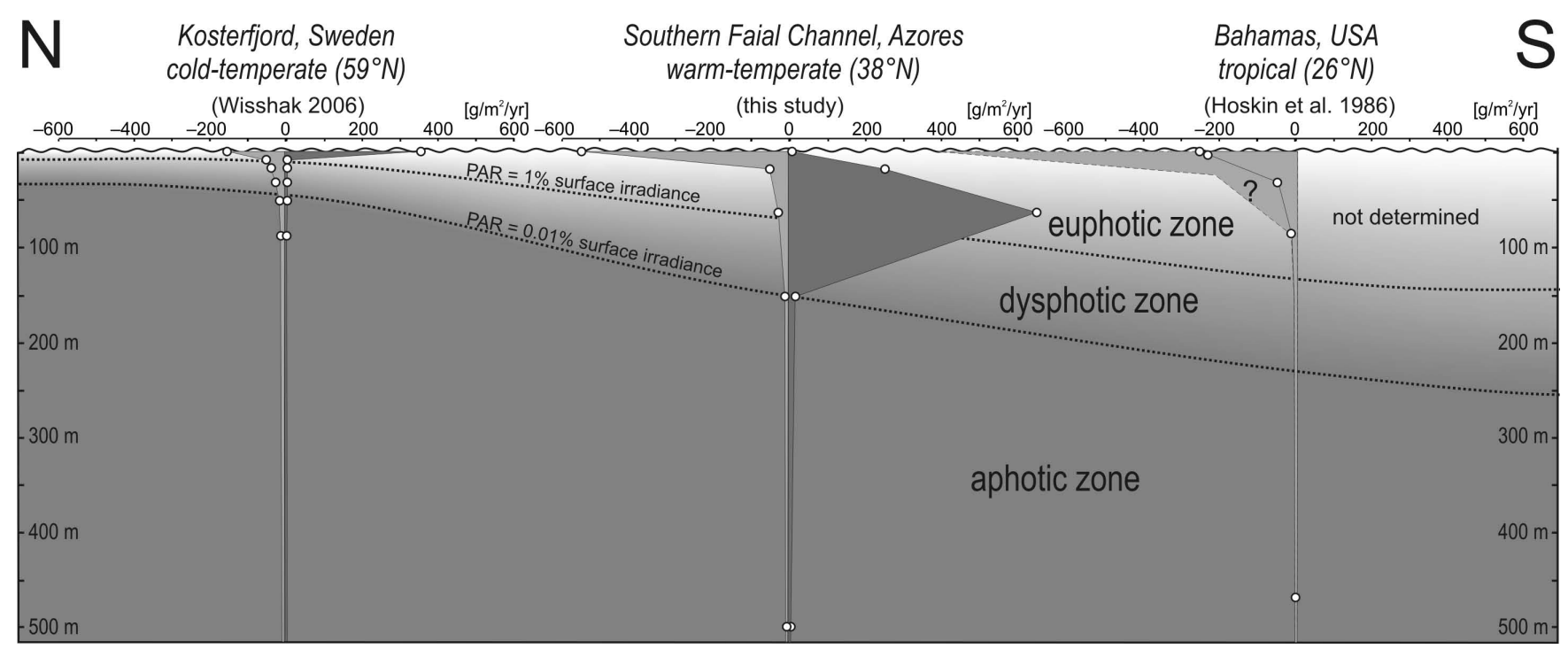

Fig. 7. Carbonate bioerosion and accretion rates along a latitudinal and environmental gradient of the N-Atlantic from the cold-temperate Kosterfjord (data from Wisshak, 2006; up-facing substrates only), to the warm-temperate Azores archipelago, to the tropical Bahamas (data from Hoskin et al., 1986; 3-D substrates). In addition, the vertical extend of the photic zonation is illustrated (data from Wisshak et al., 2005 and Vogel et al., 2000).

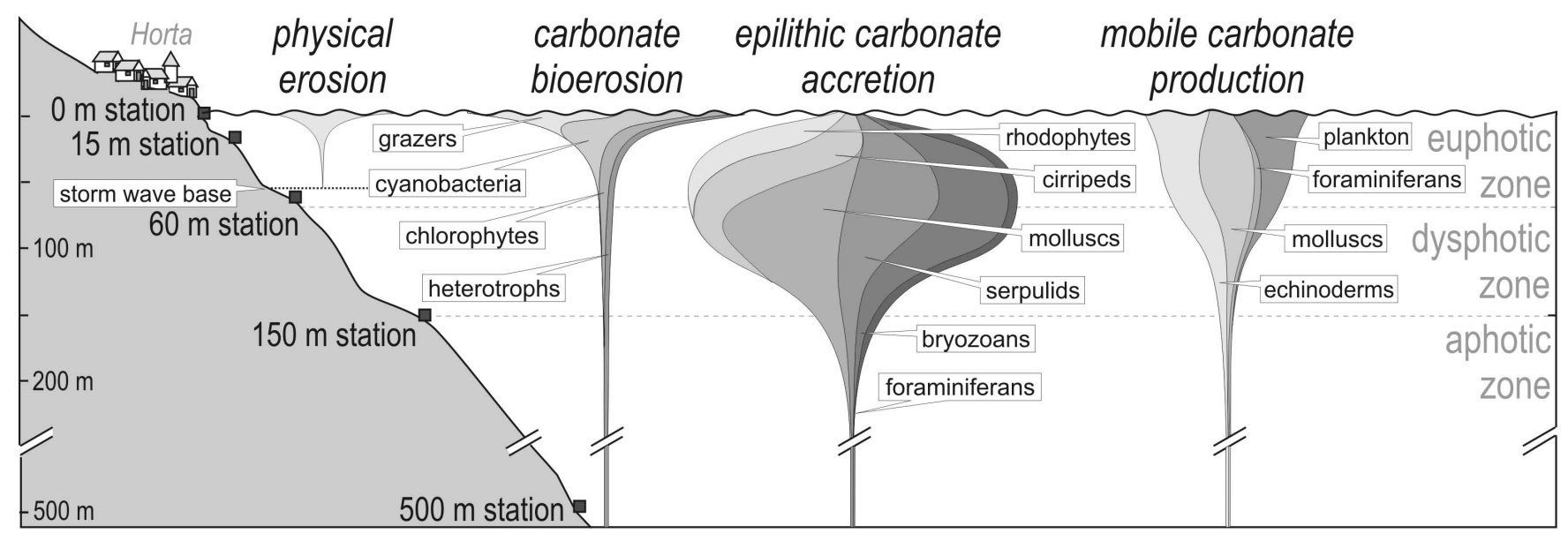

Fig. 8. Summary of processes as well as principal organism groups involved in carbonate production and degradation in the Azores carbonate $\mathrm{C}$ factory in relation to bathymetry, hydrodynamic force, and photic zonation.

is also evident at the $15 \mathrm{~m}$ station, where many eroded and later overgrown bases of serpulid worms and other epibionts were encountered. Hence, in these shallow depths, both the actual rate of epilithic carbonate production and the overall rate of carbonate degradation must in fact be considered somewhat higher than experimentally determined.

When comparing the Azores $\mathrm{C}$ factory with the general characteristics of the subtropical to tropical (T) factory (sensu Schlager, 2000) it is apparent that both factory types differ with respect to the depth range of maximum epilithic carbonate production. Carbonate accretion in the $\mathrm{T}$ factory is largely governed by the light dependant photozoan association (sensu James, 1997) dominated by zooxanthellate corals and crustose rhodophytes, and is thus most intense in the zone of light saturation in the upper $\sim 20 \mathrm{~m}$ of the euphotic zone (Bosscher and Schlager, 1992; Schlager, 2005). In contrast, in the Azores $\mathrm{C}$ factory the carbonate accretion is most intense at the $15 \mathrm{~m}$ station and particularly at the $60 \mathrm{~m}$ station as a result of less light-dependence of the supporting heterozoan assemblage. This is despite the fact that some of the carbonate is eroded by wave action and transported downslope, and it is very unlikely that physical erosion alone could account for the observed 5 to 1000 fold lower accretion rates in the intertidal and at $15 \mathrm{~m}$ depth if compared to the $60 \mathrm{~m}$ station. Instead, the hydrodynamic force prohibits the development of more erect and inevitably more fragile 
epilithobionts that could promote a higher carbonate production in the first place, whereas in the tropics, colonial corals in concert with crustose rhodophytes and rapid marine cementation form a calcareous framework that is much more resistant to hydrodynamic force.

For budgeting the total epilithic carbonate accretion and the bioerosion on the bathymetrical transect, the rates obtained for the various depth stations can be implemented in a linear approximation via the trapeze formed by the depth intervals and respective rates $(r)$ at the delimitating depth stations $(d)$. The resulting overall rate can then be expressed as total annual carbonate accretion, bioerosion, or net carbonate production for a $1 \mathrm{~m}$ wide seafloor transect (0 to $500 \mathrm{~m}$ ). Considering a representative submarine slope angle for the islands of Faial and Pico of $\alpha=10^{\circ}$, as estimated via 20 random samples of the distance between the 0 and $500 \mathrm{~m}$ bathymetrical contours (IGCP, 1969), this equates as follows:

$\sum_{i=1}^{4} \frac{r_{d_{i-1}}+r_{d_{i}}}{2} \cdot\left(d_{i}-d_{i-1}\right) / \sin \alpha$

$d_{0}$ to $4=0,15,60,150,500(\mathrm{~m}) ; \alpha=10^{\circ} ; r=$ rate $\left(\mathrm{kg} / \mathrm{m}^{2} / \mathrm{yr}\right)$

Applying the experimentally determined mean values for epilithic carbonate accretion, bioerosion, and net production for both substrate types, orientations and exposure times, this amounts to an annual $307.4 \mathrm{~kg}$ of carbonate production, $-46.8 \mathrm{~kg}$ of carbonate bioerosion, and $260.7 \mathrm{~kg}$ of net carbonate production per metre of coastline. Introducing another variable, namely an estimation of the relative proportion of up-facing versus down-facing substrates in a ratio of $3: 1$, the integration yields an annual $266.9 \mathrm{~kg}$ of carbonate production, $-54.6 \mathrm{~kg}$ of carbonate bioerosion and $212.3 \mathrm{~kg}$ of net carbonate production per metre of coastline. An extension towards abyssal depths would not considerably alter this budget, since carbonate production and degradation rates strongly decrease with depth (Figs. 7-8).

This approximation bears both components of over- as well as underestimation - and thus potential for refinement that are beyond the scope of this paper. For example, not the entire seafloor is composed of a hard ground suitable for colonisation by epilithobionts, and the obtained rates reflect accretion on pristine substrate, both leading to overestimation. On the other hand, by the end of the exposure periods, some of the accreted skeletons were already attacked by bioerosion and others were removed from the substrate by hydrodynamic force, both leading to underestimation. Fortunately, positive and negative effects balance each other to a certain degree. The limitation in hardground availability for instance is somewhat counterbalanced by the fractal threedimensionality of the available substrate. Likewise, the elevated pace of carbonate accretion on pristine substrate is most significant in the shallow water where it is counterbalanced by carbonate degradation due to enhanced bioerosion as well as hydrodynamic force. Hence, considering the present availability of experimental data, the figures obtained herein can serve as a reasonable estimation for epilithic carbonate production, bioerosion and net accretion in the typical $\mathrm{C}$ factory setting of the Azores Archipelago and may serve as basis for future three-dimensional modelling of carbonate as well as carbon cycling.

\section{Conclusions}

In the Azores, intense carbonate production and accumulation is taking place primarily in the photic zone above $150 \mathrm{~m}$ of water depth as a combination of epilithic calcifying heterozoans in concert with few phototrophic algae, and - to a lesser degree - skeletal growth of mobile benthos. Typically for a $\mathrm{C}$ factory, carbonate production is almost exclusively biotically controlled, whereas abiotic precipitation and biotically induced carbonate precipitation can be neglected.

Water mass properties in the Azores $\mathrm{C}$ factory are characterised via in situ data loggers and analyses of water samples as follows: Seasonal sinusoidal sea-surface temperatures reach a maximum mean of $22.3^{\circ} \mathrm{C}$ in September and lowest mean value of $15.6^{\circ} \mathrm{C}$ in March with a decrease in amplitude and absolute values with depth. Short-term fluctuations co-vary with the tidal rhythm and reach $5^{\circ} \mathrm{C}$ in $60 \mathrm{~m}$ depth close to the shifting summer thermocline, whereas in the springtime temperatures converge and stratification diminishes. The seawater $\delta^{18} \mathrm{O}_{\mathrm{SW}}$ and $\delta^{13} \mathrm{C}_{\mathrm{DIC}}$ stable isotope signatures decrease with depth from an average of $0.82 \%$ and $1.30 \%$ at the sea surface down to $0.55 \%$ V-SMOW and $0.57 \%$ o PDB, respectively, at $500 \mathrm{~m}$ depth. Dissolved nutrients (ammonium, nitrite, nitrate, and phosphate) likewise decrease with depth and exhibit a $\mathrm{N}$ limitation in the shallower waters due to planktonic primary production. Carbonate system parameters are within normal limits with a decrease in calcium carbonate saturation states, corresponding to an increase in $\mathrm{fCO}_{2}$ with depth. Photosynthetic active radiation profiles reflect a light regime with a base of the euphotic zone in $\sim 70 \mathrm{~m}$ and a lower delineation of the dysphotic zone in $\sim 150$ m water depth.

Carbonate cycling rates were assessed gravimetrically via carbonate-accretion on PVC settlement plates and bioerosion of limestone substrates. Being primarily a function of light availability for photoautotrophic endoliths and grazers feeding upon them, bioerosion in the photic zone is $\sim 10$ times stronger on the illuminated upside versus the shaded underside of the platforms with maximum rates found in the intertidal $\left(-631 \mathrm{~g} / \mathrm{m}^{2} / \mathrm{yr}\right)$. Bioerosion rapidly weakens towards deeper waters where carbonate cycling by epibenthic/endolithic communities is slow. Accretion rates are highest in the lower euphotic zone $\left(955 \mathrm{~g} / \mathrm{m}^{2} / \mathrm{yr}\right)$, where the substrate is less prone to hydrodynamic force. Inversely to bioerosion, highest accretion rates are found on downfacing substrates, suggesting that bioerosion may be a key factor governing the preferential settlement and growth of 
calcareous epilithobionts on down-facing substrates, adding to lower predation pressure, lower competition with epiphytes, and avoided sediment smothering.

Evaluating the present carbonate cycling rates in context of a latitudinal and environmental gradient roughly following the course of the Gulf Stream, the Azores values plot inbetween corresponding results from previous experiments in the cold-temperate Swedish Kosterfjord and the tropical Bahamas. The overall latitudinal range of carbonate production and degradation spans up to two orders in magnitude.

Carbonate budget calculations for the bathymetrical transect, via a linear approximation using the trapeze formed by the depth intervals and respective rates, yield a mean $266.9 \mathrm{~kg}$ of epilithic carbonate production, $-54.6 \mathrm{~kg}$ of bioerosion, and $212.3 \mathrm{~kg}$ of annual net carbonate production per metre of coastline, considering an average slope of $10^{\circ}$ and a ratio of up-facing versus down-facing substrate of 3:1. This approximation bears components of over- and underestimation that balance each other to a certain degree, so that it represents a reasonable estimation for the Azores $\mathrm{C}$ factory.

Acknowledgements. Kai Schulz (Kiel, Germany) and Matthias López Correa (Erlangen, Germany) are thanked for valuable discussion and a critical screening of an earlier draft of this manuscript, and Christian Schick (Wendlingen, Germany) for verifying the mathematical approach of the carbonate budgeting. Helmut Zibrowius (Marseille, France) and Björn Berning (Linz, Austria) handled the taxonomical identification of the serpulid worms and bryozoans, respectively. Wolfgang Schlager (Amsterdam, Netherlands) and an anonymous referee provided thorough reviews that helped improving this manuscript. This study was financially supported by the Deutsche Forschungsgemeinschaft (DFG Fr 1134/12).

Edited by: W. Kiessling

\section{References}

Adkins, A., Henderson, G. M., Wang, S.-L., O'Shea, S., and Mokadem, F.: Growth rates of the deep-sea scleractinia Desmophyllum cristagalli and Enallopsammia rostrata, Earth Planet. Sci. Lett., 227, 481-490, 2004.

Betzler, C., Brachert, T. C., and Nebelsick, J.: The warm temperate carbonate province - A review of the facies, zonation, and delimitations, Cour. Forsch.-Inst. Senckenberg, 201, 83-99, 1997.

Bigg, G. R. and Rohling, E. J.: An oxygen isotope data set for marine water, J. Geophys. Res., 105, 8527-8535, 2000.

Bosscher, H. and Schlager, W.: Computer simulation of reef growth, Sedimentology, 39, 503-512, 1992.

Budd, D. A. and Perkins, R. D.: Bathymetric zonation and paleoecological significance of microborings in Puerto Rican shelf and slope sediments, J. Sed. Petrol., 50, 881-904, 1980.

Connell, S. D.: Effects of surface orientation on the cover of epibiota, Biofouling, 14, 219-226, 1999.

Crisp, D. J.: Factors influencing the settlement of marine invertebrate larvae, in: Chemoreception in marine organisms, edited by: Grant, P. T. and Mackie, A. M., Academic Press, London, 177-265, 1974.

Doney, S. C., Fabry, V. J., Feely, R. A., and Kleypas, J. A.: Ocean Acidification: The Other $\mathrm{CO}_{2}$ Problem, Ann. Rev. Mar. Sci., 1, 169-192, 2009.

Dickson, A. G., Afghan, J. D., and Anderson, G. C.: Reference materials for oceanic $\mathrm{CO}_{2}$ analysis: a method for the certification of total alkalinity, Mar. Chem., 80, 185-197, 2003.

Dickson, A. G. and Millero, F. J.: A comparison of the equilibrium constants for the dissociation of carbonic acid in seawater media, Deep-Sea Res. A., 34, 1733-1743, 1987.

Fasham, M. J. R., Platt, T., Irwin, B., and Jones, K.: Factors affecting the spatial pattern of the deep chlorophyll maximum in the region of the Azores front, Prog. Oceanogr., 14, 129-165, 1985.

Glasby, T. M.: Surface composition and orientation interact to affect subtidal epibiota, J. Exp. Mar. Biol. Ecol., 248, 177-190, 2000.

Glaub, I.: Mikrobohrspuren in ausgewählten Ablagerungsräumen des europäischen Jura und der Unterkreide (Klassifikation und Palökologie), Courier. Forsch.-Inst. Senckenberg, 174, 1-324, 1994.

Golubic, S., Perkins, R. D., and Lukas, K. J.: Boring microorganisms and microborings in carbonate substrates, in: The study of trace fossils, edited by Frey, R. W., Springer Verlag, Berlin Heidelberg, 229-259, 1975

Hansen, H. P. and Koroleff, F.: Determination of nutrients, in: Methods of Seawater Analysis, edited by: Grasshoff, K., Kremling, K., and Ehrhardt, M., Verlag Chemie, Weinheim, 159-228, 1999.

Hassan, M.: Modification of carbonate substrate by bioerosion and bioaccretion on coral reefs of the Red Sea. Shaker, Aachen, 1998.

Holmes, R. M., Aminot, A., Kerouel, R., Hooker, B. A., and Peterson, B. J.: A simple and precise method for measuring ammonium in marine and freshwater ecosystems. Can. J. Fish. Aquat. Sci., 56, 1801-1808, 1999.

Hoskin, C. M., Reed, J. K., and Mook, D. H.: Production and offbank transport of carbonate sediment, Black Rock, southwest Little Bahama Bank, Mar. Geol., 73, 125-144, 1986.

IGCP (Instituto Geográfico e Cadastral): Arquippélago dos Açores - Ilhas do Faial e Pico (W) 1:50000, Serie m 7811, 1969.

James, N. P.: The cool-water carbonate depositional realm, in: Cool-water Carbonates, edited by: James, N. P., Clarke, J. A. D., SEPM Spec. Publ., 56, 1-20, 1997.

Jerlov, N. G.: Optical Oceanography, Elsevier Oceanography Series 5, Elsevier, Amsterdam, 1968.

Jerlov, N. G.: Marine Optics, Elsevier, Amsterdam, 1976.

Lafon, V., Martins, A., Figueiredo, M., Melo Rodrigues, M. A., Bashmchnikov, I., Mendonça, A., Macedo, L., and Goulart, N.: Sea surface temperature distribution in the Azores Region. Part I: AVHRR imagery and in situ data processing, Life and Marine Sciences 21A, 1-18, 2004.

Langdon, C., Takahashi, T., Sweeney, C., Chipman, D., Goddard, J., Marubini, F., Aceves, H., Barnett, H., and Atkinson, M. J.: Effect of calcium carbonate saturation state on the calcification rate of an experimental coral reef, Global Biogeochem. Cy., 14, 639-654, 2000.

LeGrande, A. N. and Schmidt, G. A.: Global gridded data set of the oxygen isotopic composition in seawater, Geophys. Res Lett., 33, L12604, doi:10.1029/2006GL026011, 2006.

Lewis, E. and Wallace, D. W. R.: Program Developed for $\mathrm{CO}_{2}$ Sys- 
tem Calculations, ORNL/CDIAC-105, Carbon Dioxide Information Analysis Center, Oak Ridge National Laboratory, U.S. Department of Energy, Oak Ridge, Tennessee, USA, http://cdiac. ornl.gov/oceans/co2rprt.html, last access: August 2010, 1998.

Lorenzo, L. M., Figueiras, F. G., Tilstone, G. H., Arbones, B., and Mirón, I.: Photosynthesis and light regime in the Azores front region during summer: are light-saturated computations of primary production sufficient?, Deep-Sea Res. Pt. I, 51, 1229-1244, 2004.

Manzello, D. P., Kleypas, J. A., Budd, D. A., Eakin, C. M., Glynn, P. W., and Langdon, C.: Poorly cemented coral reefs of the eastern tropical Pacific: Possible insights into reef development in a high- $\mathrm{CO}_{2}$ world, P. Natl. Acad. Sci. USA, 105, 10450-10455, 2008.

Marali, S., Wisshak, M., McCulloch, M., and Freiwald, A.: Microstructure, stable isotope analysis and trace elemental composition of Caryophyllia cyathus and Desmophyllum cristagalli, in: Paläontologie - Schlüssel zur Evolution, edited by: Martin, T. and Kaiser, S. I., 79. Jahrestagung der Paläontologischen Gesellschaft, 5-7 October 2009, Bonn, Terra Nostra, 2009(3), 77-78, 2009.

Martins, H. R.: A selected bibliography of the marine fauna and flora of the Azores, Arquipélago, 8, 35-44, 1990.

Marubini, F., Barnett, H., Langdon, C., and Atkinson, M. J.: Dependence of calcification on light and carbonate ion concentration for the hermatypic coral Porites compressa, Mar. Ecol.-Prog. Ser., 220, 153-162, 2001.

Matsumoto, A.: Estimation of in situ distribution of carbonate produced from cold-water octocorals on a Japanese seamount in the NW Pacific, Mar. Ecol.-Prog. Ser., 399, 81-102, 2009.

Mehrbach, C., Culberson, C. H., Hawley, J. E., and Pytcowicz, R. M.: Measurement of the apparent dissociation constants of carbonic acid in seawater at atmospheric pressure, Limnol. Oceanogr., 18, 897-907, 1973.

Morato, T., Machete, M., Kitchingman, A., Tempera, F., Lai, S., Menezes, G., Santos, R. S., and Pitcher, T. J.: Abundance and distribution of seamounts in the Azores, Mar. Ecol.-Prog. Ser., 357, 17-21, 2008.

Piazena, H., Perez-Rodrigues, E., Häder, D.-P., and LopezFigueroa, F.: Penetration of solar radiation into the water column of the central subtropical Atlantic Ocean - optical properties and possible biological consequences, Deep-Sea Res. Pt. II, 49, 3513-3528, 2002.

Redfield, A., Ketchum, B., and Richards, F.: The influence of organisms on the composition of sea water, in: The sea, edited by: Hill, M. N., Wiley, New York, USA, 26-77, 1963.

Rogers, A. D.: The biology of seamounts, Adv. Mar. Biol., 30, 305350, 1994.

Santos, R. S., Hawkins, S., Monteiro, L. R., Alves, M., and Isidro, E. J.: Marine research, resources, and conservation in the Azores, Aquat. Conserv., 5, 311-154, 1995.

Schlager, W.: Sedimentation rates and growth potential of tropical, cool-water and mud-mound carbonate factories, in: Carbonate Platform Systems: Components and Interactions, edited by: Insalaco, E., Skelton, P. W., Palmer, T. J., Geol. Soc. Spec. Publ., 178, 217-227, 2000

Schlager, W.: Benthic carbonate factories of the Phanerozoic, Int. J. Earth. Sci., 92, 445-464, 2003.

Schmidt, G. A., Bigg, G. R., and Rohling, E. J.: Global Seawa- ter Oxygen-18 Database (vers 1.19), http://data.giss.nasa.gov/ o18data/, last access: August 2010, 1999.

Scoffin, T. P., Stearn, C. W., Boucher, D., Frydl, P., Hawkins, C. M., Hunter, I. G., and MacGeachy, J. K.: Calcium carbonate budget of a fringing reef on the west coast of Barbados, Bull. Mar. Sci., 30, 475-508, 1980.

Simões, A., Duarte, R., and Alves, M.: A pilot ocean monitoring site at Azores islands, Elsevier Oceanography Series, 62, 444451, 1997.

Stearn, C. W., Scoffin, T. P., and Martindale, W.: Calcium carbonate budget of a fringing reef on the west coast of Barbados, Bull. Mar. Sci., 27, 479-510, 1977.

Stoll, H. M., Ruiz-Encinar, J., Garcia-Alonso, J. I., Rosenthal, Y., Klaas, C., and Probert, I.: A first look at paleotemperature prospects from $\mathrm{Mg}$ in coccolith carbonate: cleaning techniques and culture measurements, Geochem. Geophys. Geosy., 2, 14 pp., doi:10.1029/2000GC000144, 2001.

Tempera, F.: Benthic habitats of the extended Faial Island Shelf and their relationship to geologic, oceanographic and infralittoral biologic features. Ph.D. thesis. University of St. Andrews, http: //hdl.handle.net/10023/726, last access: August 2010, 2009.

Tempera, F., Afonso, P., Morato, T., Prieto, R., Silva, M., Cruz, A., Gonçalves, J., and Santos, R. S.: Biological assemblages of the Faial-Pico Channel SACs, Departamento de Oceanografia e Pescas da Universidade dos Açores, Horta, Arquivos do DOP, Série Relatórios Internos, 7, 2001a.

Tempera, F., Afonso, O., Morato, T., Gubbay, S., Dentinho, T., Silva, M., Prieto, R., Cardigos, F., Pitta, M. J., and Santos, R. S.: Technical-scientific management proposal for the Faial-Pico Channel SACs, Departamento de Oceanografia e Pescas da Universidade dos Açores, Horta, Arquivos do DOP, Série Relatórios Internos, 8, 2001b.

UNESCO: Background papers and supporting data on the practical Salinity Scale 1978, UNESCO Technical Papers in Marine Science, 37, 1-144, 1981.

Vogel, K., Kiene, W. E., Gektidis, M., and Radtke, G.: Scientific results from investigations of microbial borers and bioerosion in reef environments, Göttinger Arb. Geol. Pal., Sonderb., 2, 139143, 1996.

Vogel, K., Gektidis, M., Golubic, S., Kiene, W. E., and Radtke, G.: Experimental studies on microbial bioerosion at Lee Stocking Island, Bahamas and One Tree Island, Great Barrier Reef, Australia: implications for paleoecological reconstructions, Lethaia, 33, 190-204, 2000.

Wendt, P. H., Knott, D. M., and Van Dolah, R. F.: Community structure of the sessile biota on five artificial reefs of different ages, Bull. Mar. Sci., 44, 1106-1122, 1989.

Wisshak, M.: High-Latitude Bioerosion: The Kosterfjord Experiment, Springer Verlag, Berlin Heidelberg, Lecture Notes in Earth Sciences, 109, 2006.

Wisshak, M., Gektidis, M., Freiwald, A., and Lundälv, T.: Bioerosion along a bathymetric gradient in a cold-temperate setting (Kosterfjord, SW Sweden): an experimental study, Facies, 51, 93-117, 2005.

Wisshak, M., López Correa, M., Zibrowius, H., Jakobsen, J., and Freiwald, A.: Skeletal reorganisation affects geochemical signals, exemplified in the stylasterid hydrocoral Errina dabneyi (Azores Archipelago), Mar. Ecol.-Prog. Ser., 397, 197-208, 2009a. 
Wisshak, M., Neumann, C., Jakobsen, J., and Freiwald, A.: The 'living-fossil community' of the cyrtocrinid Cyathidium foresti and the deep-sea oyster Neopycnodonte zibrowii (Azores Archipelago), Palaeogeogr. Palaeoclimatol. Palaeoecol., 271, 77-83, 2009b.
Wisshak, M., López Correa, M., Gofas, S., Salas, C., Taviani, M., Jakobsen, J., and Freiwald, A.: Shell architecture, element composition, and stable isotope signature of the giant deep-sea oyster Neopycnodonte zibrowii sp. n. from the NE Atlantic, Deep-Sea Res. Pt. I, 56, 374-404, 2009c.

Zeff, M. L. and Perkins, R. D.: Microbial alteration of Bahamian deep-sea carbonates. Sedimentology, 26, 175-201, 1979. 